\title{
Finska domar i brottmål 1970-1971
}

\author{
Av justitierådet VIKING MODEEN, Helsingfors
}

Tidigare översikter över kriminalrättsliga avgöranden i Finland har ingått i denna tidskrift åren 1954, 1955, 1960, 1963 och 1970. Nu föreliggande översikt berör dylika avgöranden under åren 1970 och 1971. Då översikten hänför sig till en så pass kort tidsperiod har det varit möjligt att något utförligare redogöra för en del rättsfall, vilka måhända kunna påräkna större intresse. $\left.{ }^{1}\right)$ Det har synts mig även vara skäl att i samband med några redogörelser i korthet ingå på vissa i finsk strafflagstiftning på senaste tid gjordla tillägg och ändringar. Sålunda har i finsk strafflag införts det s. k. obetydliga brottet. Stadgandena angående misshandel och försnillning har ändrats och det straffrättsliga hemfridsskyddet har utsträckts att omfatta även olovlig avlyssning och olovlig observation.

\section{Straffrättens tillämpningsområde.}

1. På åtal av vederbörande tullåklagare förklarade RR bl. a. utrett, att X, som var finsk medborgare, hade A) i maj-juni 1966 tillsammans med bl. a. endel svenska medborgare inköpt i Polen 200.000 cigaretter och, i avsikt att bereda sig nytta, undandragande statsverket tillkommande tullavgift fört dem med motorfartyget Stina till Gotland, samt år 1967 infört till Gotland olovligen alkoholdrycker och, i avsikt att bereda sig nytta, undandragande statsverket tillkommande tullavgift cigaretter, B) i juni tillsammans med bl. a. endel svenska medborgare med fiskefartyget Fylgia från Stralsund 3.000 flaskor alkoholdrycker och 500.000 cigaretter samt $\mathrm{C}$ ) den 10 eller 11 juli tillsammans med bl. a. endel svenska medborgare med fiskefartyget Condor från ett okänt fartyg på östersjön 6.000 flaskor alkoholdrycker, varför RR med stöd av $82 \S 1 \mathrm{mom}$. alkohollagen 26/7 $1968 \mathrm{samt}$ 38 kap. 11 och 7 kap. 1 och $2 \S \S$ strafflagen dömde X för i punkt A) omförmälda, under synnerligen försvårande omständigheter begångna tullförsnillning samt för i punkterna B) och $\mathrm{C}$ ) omförmälda fortsatta brott, som innebar smuggling av alkoholhaltigt ämne och under synnerligen försvårande omständigheter förövad tullförsnillning, begångna i en gärning, och smuggling av alkoholhaltigt ämne, till fängelsestraff. X sökte ändring. HovR: enär införande av vara till Sverige från tredje stats om-

1) Såsom i tidigare redogörelser hänvisa sifforna till Högsta Domstolens (HD) redogörelser och meddelanden, varvid I betecknar redogörelser och II medelanden. - Förkortningar: HR = häradsrätt, RR $=$ rådstuvurätt och HovR $=$ hovrätt. 
råde, olovligen eller med undandragande av svenska staten tillkommande tullavgift, såsom riktat mot annan stat än Finland icke enligt de av RR tillämpade lagrummen eller eljest enligt finsk lag är en straffbar handling, ogillade HovR, med upphävande av RR:s utslag, åtalet till sagda del såsom icke grundat å lag. Advokatfiskalen i tullstyrelsen anhöll om prejudikatdispens. - HD beviljade fullföljdstillstånd och resolverade: ej ändring. En ledamot anmälde skiljaktig mening beträffande motiveringen. II $5 / 1971$.

Ovan relaterade utgör en del av ett större mål angående tullförsnillning och smuggling av alkoholhaltigt ämne, som avgjordes av HD 21/1 1971. För tullförsnillning straffas enligt finsk lag den som, för att bereda sig eller annan nytta, svikligen undandrager eller söker undandraga staten eller kommun tullavgift eller annan skatt eller allmän utskyld (38 kap. 11 §). (Genom en lagändring 30/6 1972, som träder i kraft 1/9 1972, har begreppet tullförsnillning undergått en viss ändring). Den, som gör sig skyldig till olovlig införsel eller utförsel av alkoholdryck eller försök därtill, dömes åter till straff för smuggling av alkoholhaltigt ämne ( $82 \S$ alkohollagen). I detta rättsfall har HD alltså intagit den ståndpunkten, att införande av vara från en främmande stat till en annan främmande stat, olovligen eller med undandragande av sistnämnda stat tillkommande tullavgift, icke är en straffbar handling enligt finsk lag. I enlighet härmed fastslog HD även i nämnda rättsfall, att befattningstagande med vara, som från främmande stat införts till annan främmande stat med undandragande av sistnämnda stat tillkommande tullavgift ej heller är ett brott enligt finsk lag. Efter att först hava fastslagit grundsatsen, att enligt finsk lag dömes den som begått brott i Finland stadgar den finska strafflagen: „Finsk medborgare och i Finland varaktigt bosatt utlänning dömas enligt finsk lag även för brott, som han förövat utom Finland“ (1 kap. 2 §). Sistnämnda stadgande är rätt så kategoriskt avfattat. Enligt lagberedningens förslag till Regeringens proposition till Riksdagen angående revision av lagstiftningen om tillämpningsområdet för finsk straffrätt (Lagberedningens publikation $n: 0 \quad 3$ år 1962) framhålles emellertid, att detta stadgande avser att draga upp de yttersta gränserna för den finska straffrättens tillämpningsområde $\mathrm{i}$ förevarande fall. Det borde nämligen beaktas, att största delen av de utom Finland begångna brott, som sålunda formellt skulle falla under finsk lag, är av den art att de, då kriminaliseringen enligt finsk lag inskränker sig till att skapa skydd endast för landets egna intressen, icke skulle bestraffas enligt finsk lag. Såsom sådana brott må nämnas t. ex. de, vilkas straffstadganden skyddar statens finansiella intressen, såsom skatte- och tullbrott. Till denna kategori kunde vidare hänföras brotten mot 
den ekonomiska och sociala lagstiftningen samt brott mot myndigheter och allmän ordning. Regeringens proposition N:o 13 till 1963 års Riksdag angående revision av lagstiftningen om tillämpningsområdet för finsk straffrätt bygger på lagberedningens nyssnämnda förslag. I lagutskottets betänkande samt i Riksdagens svar på sagda proposition omnämnes, att omförmälda stadgande utgör de yttersta gränserna för den finska. straffrättens tillämpningsområde i förevarande avseende och att väckande av åtal vid finsk domstol i alla de fall stadgandet avser icke kan komma ifråga. - Vilken hade situationen varit, om ifrågavarande alkoholdrycker och cigaretter införts till Sverige, icke från tredje stats område, utan från Finland? Till denna fråga hade HD i förevarande fall icke direkt anledning att taga ståndpunkt, men det förefaller, som om någon principiell skillnad härvidlag icke förelåge; även i detta fall fölle införandet utanför finsk kriminaljustis, och detta vare sig varorna utförts från Finland lovligen eller olovligen. - I detta sammanhang må nämnas, att HD i rättsfallet II 40/1967 ansett, att framförande av motorfordon utan vederbörligt tillstånd, som begåtts utom Finland, icke är en straffbar handling enligt finsk lag (Finska domar i brottsmål 1961-1969, årgång 1971, rättsfall 31).

\section{Obetydligt brott.}

2. Advokatfiskalen anförde vid HovR, att A i egenskap av justitierådman vid Nyslotts RR medelst $30 / 9 \quad 1965$ utfärdad strafforder dömt B med stöd av 43 kap. $6 \S 1$ mom. strafflagen för 12/9 1964 i sagda stad begånget fylleri till 40 dagsböter á $40 \mathrm{mk}$ och att, enär rätten att åtala det $\mathrm{B}$ tillräknade brottet vid tidpunkten för utfärdandet av straffordern på grund av stadgandet i 8 kap. $1 \S 1$ mom. 5 punkten i sagda lag förfallit, HD medelst 21/2 1968 givet utslag med stöd av 31 kap. $8 \S 4$ punkten rättegångsbalken undanröjt nämnda strafforder. Då straffordern i omförmält avseende var felaktig, yrkade advokatfiskalen, att $\mathrm{A}$, vilken sagda felaktighet sålunda bör tillräknas, med stöd av 40 kap. $21 \S$ strafflagen skulle ådömas straff för av oaktsamhet $\mathrm{i}$ domarämbete begånget tjänstefel. - HovR förklarade utrett, att $\mathrm{A}$ gjort sig saker till det, som honom påbördats, men enär ifrågavarande brott var obetydligt och det borde anses hava berott på ouppmärksamhet, som med beaktande av omständigheterna var ursäktlig och allmänt intresse icke fordrade ådömande av straff, lämnade HovR med stöd av 3 kap. 5 § 2 mom. strafflagen A för sagda gärning obestraffad. - HD: enär A:s omförmälda förfarande, vilket medfört, att B kommit att utstå ett bötesstraff, vartill han enligt lag icke skulle kunnat fällas, icke kunde anses för ett obetydligt brott, dömde HD med stöd av 40 kap. $21 \S$ strafflagen $\mathrm{A}$ att för ifrågavarande förfa- 
rande, vilket bör tillräknas honom såsom av oaktsamhet begånget tjänstefel, erhålla varning. - Två ledamöter ansåg skäl icke hava anförts till ändring i HovR:s utslag. II 70/1970.

Det obetydliga brottet infördes i finsk strafflagstiftning år 1966. - I finsk straffrätt har intill senaste tid vad den allmän åklagare tillkommande åtalsbefogenheten beträffar den s.k. legalitetsprincipen varit nästan uteslutande gällande. Jämlikt $15 \S$ 1 mom. förordningen om införande av strafflagen 19/12 1889 var allmän åklagare sålunda pliktig att åtala brott, som hörde under allmänt åtal, ändå att målsäganden icke anmält det därtill. För målsägandebrott var allmän åklagare enligt $18 \S$ samma förordning även skyldig att utföra åtal, om målsäganden angav brottet till åtal. Allmän åklagare fick avstå från att väcka åtal endast om bevisen för angivelsen var så ringa, att den icke var grundad på sannolika skäl. Domstol var pliktig att, då åtal väckts och styrkts, döma den ătalade till straff enligt lag. Från nyssnämnda princip stadgades emellertid vissa undantag, vilka rörde dels vissa slag av personer (unga förbrytare) dels vissa brottstyper (t.ex. åverkan som förorsakat endast mycket ringa skada, skadegörelse, vid vilken åsamkats endast ringa skada, ringa trafikförseelse). I ett uppgjort förslag till Regeringens proposition till Riksdagen med förslag till ändringar i strafflagstiftningen, avseende åtalseftergift och domseftergift i vissa fall för den, som gjort sig skyldig till obetydligt brott, framhöll lagberedningen, att syftet med utövningen av statens straffbefogenhet är rättsordningens upprätthållande och garanterandet av rättsskydd åt medborgarna. I de fall, då det med tanke på detta ändamål är onödigt att döma till straff för en obetydlig förseelse; borde myndigheterna ha rätt att, oberoende av brottstyp och brottslingens ålder, lämna en sak därhän utan att väcka åtal (Lagberedningens publikation n:o 10 år 1965). Ett dylikt uttalande ingick även i Regeringens proposition till Riksdagen. Genom lagen angående ändring av förordningen om införande av strafflagen $1 / 41966$ erhöll så 15 § 2 mom. sagda förordning följande lydelse: „,̈r brott obetydligt, må allmän åklagare eftergiva åtal, om det framgår, att gärningen berott på ouppmärksamhet, tanklöshet, eller okunnighet, som med beaktande av omständigheterna är ursäktlig, och allmänt intresse icke fordrar utförande av åtal.“ Detta stadgande skall tillämpas jämväl i avseende å målsägandebrott då målsäganden angivit brottet till åtal. Och genom lagen om ändring av 3 kap. 5 § strafflagen av samma dag fogades till 3 kap. $5 \S$ sagda lag ett så lydande nytt 2 mom.: , ̈̈r brott obetydligt, må domstol lämna gärningen obestraffad, om det framgår, att gärningen berott på ouppmärksamhet, tanklöshet eller okunnighet, som med beaktande av omständigheterna är ursäktlig, och allmänt intresse icke fordrar ådömande av straff." I detta sam- 
manhang bör även stadgandena i $14 \S$ polislagen 18/2 1966 bemärkas. Enligt detta lagrum bör polisman inrapportera till sin förman brott, som kommit till hans kännedom. Men om brott är obetydligt och har, då enskild rätt genom gärningen blivit kränkt, målsäganden icke anspråk med anledning därav, kan polisman avstå ifrån att avgiva rapport om brottet och förman, ifall han erhållit rapport om brottet, avstå ifrån att vidtaga åtgärder för den skyldiges befordrande till åtal, såframt det framgår, att gärningen med beaktande av omständigheterna berott på ursäktlig ouppmärksamhet, tanklöshet eller okunnighet och att allmänt intresse icke fordrar polisens åtgärder i saken. I doktrinen har förekommit olika meningar om vad som bör förstås med obetydligt brott. Finsk kriminalrätt känner till begreppet „mindre brott“"; jämlikt $1 \S 2$ mom. lagen om strafforder $25 / 51934$ avsågs med dylikt brott ett brott, vars handläggning ankom på allmän underrätt och för vilket annat eller strängare straff än böter eller fängelse i 6 månader icke var utsatt. Det har framhållits, att med ,obetydligt brott" tydligen måste förstås ett brott, som till sin art är lindrigare än ett „,mindre brott“, varför med förstnämnda brott borde avses ett sådant, varå icke kunde följa strängare straff än böter; enligt denna uppfattning bedömes brottet abstrakt (Reino och Tauno Ellilä, Lakimies 1968 s. 566 ff). Nämnas bör, att i den nya lagen om strafforder 27/2 1970 har „mindre brott"“ ersatts med ,förseelse.“ ^ andra sidan har anförts, att man vid avgörandet av frågan, huruvida ett brott är obetydligt eller icke, bör - såsom Regeringens förenämnda proposition även synes förutsätta - utgå ifrån brottet in concreto, sådant det tagit sig uttryck i det enskilda fallet (Tuominen, Lakimies 1968 s. 554 ff). Då även i praxis förekom olika meningar om vad i förenämnda lagar av 1/4 1966 med obetydligt brott avses, införskaffade justitiekansler utredning om huru sagda lagar i förevarande avseende under förra halvåret $1967 \mathrm{i}$ praktiken tillämpats; av utredningen framgick, att i några fall åtalseftergift och domseftergift vid underrätt förekommit bl. a. beträffande brotten stöld, försnillning och bedrägeri, å vilka brott enligt den normala straffskalan följde ett högre maximistraff än fängelse i 6 månader (s. 558). Enär tolkningen av det nya stadgandet angående åtalseftergift uppvisade en viss osäkerhet meddelade justitiekansler med tanke på enhetligheten i lagtolkningen medelst skrivelse 31/7 1970 rikets allmänna åklagare vissa allmänna anvisningar härvidlag. I skrivelsen framhålles bl. a., att frågan huruvida ett brott är obetydligt skall avgöras särskilt i varje enskilt fall på basen av den konkreta form brottet antagit, utan hänsyn till brottstypen. Sålunda torde egendomsbrott $\mathrm{i}$ allmänhet kunna anses obetydligt, när skadan är ringa; även en grov stöld kan undantagsvis vara ett obetydligt brott, om gärningsmannen har 
tillgripit egendom av mycket ringa värde utan att ens försöka lägga sig till med värdefullare egendom. - Det bör observeras, att även om ett brott anses obetydligt, förutsätter åtals- eller domseftergift ytterligare, att gärningen berott på ouppmärksamhet, tanklöshet eller okunnighet, som med beaktande av omständigheterna är ursäktlig, och att ett allmänt intresse ej kräver straffåtgärder. - HD har i tre publicerade rättsfall, bl. a. i nu ifrågavarande, ansett, att stadgandet i $3 \mathrm{kap}$. $5 \S 2 \mathrm{mom}$. om obetydligt brott är tillämpligt på i 40 kap. 21 § strafflagen avsett tjänstefel. I rättsfallet II 25/1968 ansågs ordförande i krigsrätt hava förfarit felaktigt, då han vid två tillfällen vid sammanläggning av istället för arreststraff ådömda bötesstraff tillämpat den princip, som vid sammanläggning av arreststraff bör iakttagas med avseende å maximalstraffet, men då sagda förfarande, som med stöd av $158 \S$ strafflagen för krigsmakten samt 40 kap. $21 \S$ 2 mom. och 7 kap. $2 \S$ strafflagen bör tillräknas A såsom fortsatt av oskicklighet begånget tjänstefel, emellertid bör anses för ett obetydligt brott, och detsamma berott på okunnighet, som med beaktande av omständigheterna var ursäktlig, och allmänt intresse icke fordrade ådömande av straff, lämnade HD med stöd av $158 \S$ strafflagen för krigsmakten och 3 kap. $5 \S 2$ mom. strafflagen A för sagda tjänstefel obestraffad. I rättsfallet II 93/1968 ansåg HD åter att underdomares felaktiga förfarande, vilket förorsakat, att den åtalade kommit att utstå ett strängare bötesstraff än vartill han enligt lag kunnat dömas, icke utgöra ett obetydligt brott; den åtalade dömdes med stöd av 40 kap. $21 \S$ strafflagen att för sagda förfarande, vilket tillräknades honom såsom av oaktsamhet begånget tjänstefel, erhålla varning. För i 40 kap. $21 \S$ strafflagen nämnt brott dömes, där felet ej är så ringa, att den åtalade må endast med varning näpsas, till böter eller skiljande från tjänstens utövning, eller, ifall omständigheterna äro synnerligen försvårande, till avsättning. I rättsfallet II 25/1968 förekom domseftergift, i rättsfallet II 93/1968 samt i nu ifrågavarande rättsfall ansågs obetydligt brott ej föreligga och den åtalade dömdes till straff för tjänstefel. I vart och ett av sagda rättsfall prövade HD huruvida ett obetydligt brott in concreto förelåg eller icke. Man får väl antaga, att HD i framtiden kommer att tillämpa stadgandet i 3 kap. $5 \S 2$ mom. strafflagen även på andra brott än tjänstefel. Det förefaller dock som om en del grövre brott vore av den art, att de i ingen händelse kunna rubriceras såsom obetydliga brott, varför nämnda stadgande icke kunde tillämpas på desamma.

Fortsatt brott.

3. A hade i alkoholpåverkat tillstånd framfört en personbil, 3/2 1968 i Saarijärvi by av Saarijärvi kummun och 17/3 1968 i 
Jyväskylä stad. HovR. fällde A till straff för fortsatt framförande av motorfordon i sagda tillstånd. HD: enär de A tillräknade brottsliga handlingarna med beaktande av den tid som förflutit mellan dem icke kunde anses såsom fortsättning av samma brott, fälldes A till straff för två framförande av motorfordon i alkoholpåverkat tillstånd. - En ledamot ansåg, att fortsatt brott förelåg. II $58 / 1970$.

I 7 kap. 2 strafflagen stadgas: „Utgöra upprepade brottsliga handlingar fortsättning af samma brott skall straff den skyldige ådömas såsom för ett brott, men den omständighet, att brottet blivit fortsatt, gälla såsom försvårande.“ I lagrummet ingår alltså icke en definition av det fortsatta brottets begrepp. I den juridiska litteraturen har man icke kunnat enas om en uttömmande definition på sagda brott. Forsman framhåller bl. a., att mellan de särskilda handlingarna skall existera ett sådant sammanhang, att enligt den naturliga uppfattningen av sakförhållandet ingen av desamma i förhållande till de övriga framstår såsom en isolerad, självständig handling, utan envar av de följande handlingarna företer sig såsom en fortsättning av de föregående (Straffrättens allmänna läror 1893 s. 469). Såsom Honkasalo framhåller, torde man genom en allmän regel dock icke kunna fastställa, vilket sammanhang bör råda mellan de skilda handlingarna; i ifrågavarande hänseende torde man böra taga i beaktande gärningstiden och -orten för handlingarna samt de tillfällen vid vilka de brottsliga gärningarna begåtts. (Suomen rikosoikeus, Yleiset opit II s. 261). Lagstiftaren har överlämnat åt domaren att efter prövning in casu avgöra när de enskilda handlingarna skola anses stå i ett sådant förhållande till varandra, att ett fortsatt brott föreligger. Detta gäller särskilt även tidsmomentet såsom konstituerande faktor för sagda brott. I ifrågavarande rättsfall ansågs fortsatt brott icke föreligga, då c. $1 \frac{1}{2}$ månad förflutit mellan de brottsliga handlingarna, vilka utgjordes av framförande av motorfordon i alkoholpåverkat tillstånd. I rättsfallet II 79/1957 ansågs fortsatt uppträdande såsom drucken vid tjänsteförrättning föreligga, då häradshövdingen $A$ varit drucken vid upprepade tillfällen mellan 27/1 1956 och slutet av december månad samma år under tjänstgöring i domsagans arkiv samt även 24/3 1956 vid förrättande av urtima ting. Några fall må ytterligare omnämnas. I rättsfallet II 131/1955 hade B 23/11 och 21/12 1953 avhörts å ed såsom vittne i ett mål angående olovlig försäljning av alkoholdrycker och vid vartdera tillfället avgivit samma osanna utsaga; B fälldes till straff för fortsatt avgivande av osann utsaga å vittnesed. I rättsfallet II 90/1952 hade C i slutet av maj 1949 gjort sig saker till bedrägeri och under förra delen av därpåföljande juni månad till försök till nyssnämnda brott; de lägre instanserna ådömde $\mathrm{C}$ straff för bedrägeri och 
försök till bedrägeri medan HD fällde $\mathrm{C}$ till straff för fortsatt brott, som innefattade bedrägeri och försök därtill. I rättsfallet II 145/1948 åter hade D genom bedrägligt förfarande tillnarrat sig särskilda penningbelopp, 6/3 1945 av en person samt i januari 1946 vid 22 olika tillfällen av ett lika stort antal personer; det 6/3 1945 begångna bedrägeriet ansågs konstituera ett särskilt brott medan de i januari 1946 begångna bedrägerierna tillräknades D såsom ett fortsatt brolt. - Såsom Grotenfelt framhåller, utgör det fortsatta brottet egentligen ett fall av reell brottkonkurrens, som ur bestraffningssynpunkt betraktas som ett brott (Kommentar till strafflagen s. 170). Vid reell brottkonkurrens, vid vilken för varje handling utmätes ett särskilt straff, sammanläggas enligt finsk rätt de olika straffen enligt den s.k. förmedlingsprincipen d.v.s. de sammanräknade straffen läggas till grund för det gemensamma straffet, vilket dock förmildras; härav följer, att den brottslige vanligen då straffas strängare än om de särskilda handlingarna skulle tillräknas brottslingen, icke såsom särskilda brott, utan såsom fortsättning av samma brott.

\section{Befriande av fänge.}

4. På åtalan av allmän åklagare fann RR utrett, att A $19 / 5$ 1969, sedan en tjänstgörande poliskonstapel gripit B på grund av att denne i en park i Joensuu stad förtärt alkohol och av sagda orsak begynt befordra $\mathrm{B}$ till polisinrättningen, uppsåtligen genom att förgripa sig på poliskonstapeln befriat $B$, varför $R R$ med stöd av 16 kap. $10 \S 1$ mom. samt 6 kap. $2 \S$ strafflagen dömde A för befriande av fånge såsom återfallsförbrytare till fängelsestraff. Åklagaren och A sökte ändring. - HovR: ej skäl. A anhöll om prejudikatdispens. - HD beviljade fullföljdstillstånd och resolverade: ej skäl. — Två ledamöter voro av avvikande mening; den ena fastställde det slut, vartill HD kommit, enär B varit en av polisman anhållen person, den andra fällde A med stöd av 16 kap. $2 \S$ sagda lag till straff för det han gjort tjänsteman hinder i utövningen av tjänsten. II 95/1971.

Ifrågavarande rättsfall gäller tolkning av begreppet fånge i 16 kap. $10 \S 1$ mom. strafflagen. Lagrummet lyder: „Hvar, som uppsåtligen befriar fånge ur straffanstalt, häkte eller annat förvar, eller från dens vård, som bevakar, ledsagar eller forslar honom, eller hjelper fånge eller den, som rymt och bör gripas, att undkomma, straffes - - _". Att lagbudet bör tillämpas på person, som utstår det honom ådömda frihetsstraffet i straffanstalt samt i avseende å rannsakningsfångar är tämligen klart. Även vissa andra personer böra enligt positiva lagstadganden anses såsom fångar. Ung förbrytare kan förordnas att undergå det honom ådömda frihetsstraffet i ungdomsfängelse; i enlighet med stadgandet i 5 kap. 1 förordningen om verkställighet av straff 
är person, som utstår sitt straff i dylikt fängelse, fånge. Till frihetsstraff på viss tid dömd fånge i högsta klassen kan förordnas att undergå sitt straff i s.k. fångkoloni; jämlikt $10 \S$ förordningen om utstående av straff i dylik koloni 30/12 1954 är den som undergår sitt straff därstädes fånge. Likaså är på tvångsinrättning intagen enligt $13 \S 2$ mom. förordningen om tvångsinrättning 11/6 1971 fånge. - I förevarande rältsfall hade A förtärt alkohol i en park. Jämlikt $99 \S 1$ mom. 4) punkten samt $93 \S$ alkohollagen 26/7 1968 är förtäring av alkoholdryck på offentlig plats straffbelagd. I rättsfallet hade den gripne sålunda omhändertagits av polismyndighet misstänkt för brott och alltså av straffrättsliga skäl. Ifrågavarande lagrum har såsom härav framgår — vad begreppet fånge beträffar - tolkats rätt så extensivt.

\section{Misshandel m.m.}

5. Allmän åklagare yrkade A : s fällande till straff för det denne jämte en annan person natten mot 22/9 1968 i Halikko kommun löstagit tvenne fönster i ett bebott rum i jordbrukaren B:s ägande gård tillhörande uthusbyggnad och utan laga rätt inträngt $i$ rummet, åstadkommande därstädes oordning, samt därefter på gårdsplanen uppsåtligen slagit $\mathrm{C}$ med knytnäven i magen med påföljd att denne därav erhållit svår kroppsskada, vilken dock icke varit åsyftad. - HR fann utrett, att A stannade till last vad honom tillvitats och dömde A med stöd av 21 kap. $5 \S 3$ mom., 24 kap. 1 § 1 och 3 mom., 35 kap. 3 samt 7 kap. 1 § strafflagen för fortsatt brott, som innebar grov misshandel, varvid svår kroppsskada dock icke avsetts, samt i en gärning begångna hemfridsbrott och skadegörelse till fängelse i 6 månader, varjämte A ålades att ersätta den skada han åsamkat B och C. HR förordnade dock att med verkställigheten av det A ådömda frihetsstraffet jämlikt lagen om villkorlig straffdom 20/6 1918 skulle anstå under en prövotid av 5 år från det utslaget vunnit laga kraft och straffet därefter förfalla, såvida A icke genom att under prövotiden begå nytt brott eller överlämna sig åt dryckenskap eller osedligt eller eljest vanartigt leverne förverkat sin rätt till anstånd med straffets verkställighet. För att undgå straffverkställighet skulle $\mathrm{A}$ inom 4 år från det utslaget vunnit laga kraft erlägga åt $B$ och $C$ de dem tilldömda ersättningarna vid äventyr att, om A åsidosatte fullgörelsen och B eller C före prövotidens utgång därom anmälde till HR, det A ådömda straffet även av denna anledning kunde på i lag stadgade grunder förklaras gå i verkställighet. Åklagaren och $\mathrm{C}$ sökte ändring. - HovR, som fann, att A i samband med hemfridsbrottet icke gjort sig saker till skadegörelse, dömde med stöd av de av HR åberopade lagrummen, förutom 35 kap. $3 \S$ strafflagen, A för fortsatt brott, 
som innebar hemfridsbrott och misshandel, varav följt svår kroppsskada, som dock icke åsyftats, till fängelse i 11 månader. Med verkställigheten av frihetsstraffet skulle anstå på de i HR:s utslag omförmälda villkoren dock så, att A skulle utbetala ersättningarna åt $\mathrm{B}$ och $\mathrm{C}$ vid av $\mathrm{HR}$ fastställt äventyr inom 3 år från det utslaget i målet vann laga kraft. A sökte ändring. - HD: enär A då han vid omförmälda tillfälle misshandlade $\mathrm{G}$ genom att slå denne med knytnäven i magen med påföljd att $G$ erhöll svår kroppsskada, icke åsyftat att åstadkomma en dylik skada eller insett, att av slaget kunde uppkomma en dylik påföljd, men $\mathrm{A}$ bort taga $\mathrm{i}$ beaktande denna påföljd, och då på $\mathrm{A}: \mathrm{s}$ gärning sålunda borde tillämpas stadgandena i 21 kap. 5 och $10 \S \S$ strafflagen, sådana sagda lagrum lyder i lagen om ändring av strafflagen 14/7 1969, som trädde i kraft $1 / 1$ 1970, vilka stadganden äro mildare än det av de lägre instanserna å gärningen tillämpade och vid tidpunkten för gärningens begående ikraftvarande stadgandet i 21 kap. $5 \S 3$ mom. sagda lag, dömdes A med stöd av 21 kap. 5 och $10 \S \S$, sådana de lyder i sagda år 1969 givna lag, samt 24 kap. $1 \S 1$ och 3 mom. och 7 kap. 1 och $2 \S \S$ strafflagen för fortsatt brott, som innebär hemfridsbrott samt i en gärning begångna misshandel och vållande av kroppsskada till fängelse i 9 månader. Domen förklarades villkorlig på de av HovR fastställda villkoren. II 69/1970.

I förevarande rättsfall har HD ansett, att på misshandeln icke bör tillämpas de vid tidpunkten för gärningens begående ikraftvarande stadgandena utan beträffande sagda brott senare tillkomna stadganden, vilka äro mildare än de förstnämnda stadgandena. - I detta sammanhang erbjuder en kort redogörelse för vissa huvuddrag i de uppsåtliga misshandelsbrotten enligt gammal och ny lag måhända intresse. Fråga även om vid villkorlig dom fäst villkor.

1) Vilken lag bör tillämpas å misshandeln? Jämlikt 3 förordningen om införande av strafflagen 19/12 1889 skall på brott, som förövats medan äldre lag varit gällande, men varom, innan strafflagen trätt i kraft, ej blivit dömt genom dom, som vunnit eller får vinna laga kraft, den lag tillämpas, som mildare är. Detta lagrum, som är ett övergångsstadgande, vilket hänför sig till strafflagens ikraftträdande, har ansetts vara uttryck för en allmän princip, som bör tillämpas även eljest vid ändring av straffbud. Lagen uttalar sig dock icke om vad den avser med begreppet mildare lag. Såväl doktrin som praxis är dock eniga om, att med mildare lag bör förstås den lag, som i det konkreta fallet medför det mildare straffet. Lagskiparen bör sålunda upptaga rättsfallet till prövning efter såväl den lag som var i kraft då gärningen begicks som den lag som är gällande vid tidpunkten för dömandet och härvid bör avseende fästas icke allenast vid 
själva straffen, utan även vid alla de omständigheter, som kunna inverka på den åtalades rättsliga ställning, således även omständigheter, som upphäva eller förminska gärningens straffbarhet, återfall, försök, delaktighet o.s.v. Har den åtalade t.ex. gjort sig saker till försök till ett brott och försök till detta brott är straffbelagt icke enligt den lag, som var gällande då handlingen begicks, men väl jämlikt senare tillkommen lag, bör förstnämnda lag tillämpas (Forsman, Straffrättens allmänna läror $1893 \mathrm{~s} .404$, Serlachius, Suomen rikosoikeuden oppikirja Yleiset opit 1919 s. 59 samt Honkasalo, Suomen rikosoikeus Yleiset opit I s. 112).

2) Misshandel enligt gamla och nya lagen. De uppsåtliga misshandelsbrotten ingick i 21 kap. av 1889 års strafflag. De i sagda kapitel ingående stadgandena angående omförmälda brott förblev med några oväsentliga förändringar gällande tills lagen om ändring av strafflagen 14/7 1969, som helt och hållet ändrade nämnda kapitel, trädde i kraft. Strafflagen av år 1889 indelade de egentliga misshandelsbrotten med hänsyn till de av brotten förorsakade påföljderna i misshandel, som medförde svår kroppsskada, misshandel som åstadkom mindre kroppsskada samt misshandel, som medförde ringa eller ingen kroppsskada. Med svår kroppsskada avsåg lagen förlust av talförmåga, syn eller hörsel, svårt lyte eller annat svårt kroppsfel, stadigvarande svårt men å hälsa eller ock livsfarlig sjukdom eller skada. Mindre kroppsskada åter förelåg, om någon misshandlat annan så, att denne därav erhållit mindre lyte, kroppsfel eller sjukdom än vad lagen avsåg med svår kroppsskada. Ringa kroppsskada var slutligen en läsion som var obetydligare än mindre kroppsskada. Vid uppsåtlig misshandel svarade gärningsmannen för påföljden oberoende av om han avsett dennas inträdande eller ej; det förutsattes dock, att gärningen enligt livets allmänna regel kunde förväntas medföra den inträffade brottsliga effekten, m.a.o. att adekvat orsakssammanhang mellan gärning och skada förelåg. Lagen 14/7 1969 har nu frångått denna princip och utgår ifrån att gärningsmannen vid uppsåtlig misshandel svarar endast för den skada han avsett. Men om av gärningen uppkommit en ytterligare påföljd, som hans uppsåt icke omfattat, men väl kan tillräknas honom såsom vållande och vållande av denna ytterligare påföljd är straffbelagd, bör gärningsmannen dömas till straff även härför. Även lagen 14/7 1969 indelar misshandelsbrotten i tre kategorier. Först har i lagen intagits ett enkelt grundstadgande, sedan följer stadgandena rörande grövre fall och därpå stadgandena angående mildare fall (Lagutskottets betänkande n:o 11 med anledning av Regeringens proposition N:o 68 till 1966 års Riksdag). Grundstadgandet ingår i 21 kap. 5 §, enligt vilken den, som uppsåtligen förorsakar annan kroppsskada eller sjukdom, dömes för misshandel. Begreppet kroppsskada innefattar t.ex. 
olika slag av sår, krosskador, blåmärken, benbrott och sinnesdefekter; sjukdomar är förutom fysiska sjukdomar även psykiska sådana (anförda betänkande). Stadgandet om grov misshandel ingår i sagda kapitels 6 §. Dylik misshandel föreligger, om någon uppsåtligen genom i nyssnämnda 5 § nämnt brott förorsakas svår kroppsskada, allvarlig sjukdom eller livsfara eller om brottet förövas på ett sätt, som ådagalägger särskild råhet eller grymhet, eller om därvid användes vapen eller annat livsfarligt medel och för så vitt misshandeln i sagda eller övriga fall med beaktande av de omständigheter i sin helhet, vilka föranlett brottet och framgå av detsamma, bör anses grov. Nyssnämnda i 6 § särskilt uppräknade fall framhållas endast såsom exempel; lagrummet förutsätter förhandenvaron av även andra fall av kvaliciferad misshandel; om i ett dylikt fall misshandeln med beaktande av de omständigheter i sin helhet, vilka föranlett brottet och framgå av detsamma, bör anses grov, föreligger grov misshandel. I lagrummet ingår icke en definition på begreppen svår kroppsskada, allvarlig sjukdom eller livsfara. Härvidlag kan domstolarna dock stöda sig på stadgad praxis, som tolkat strafflagens av år 1889 stadgande om svår kroppsskada rätt extensivt. Gränsdragningen mellan den i $5 \S$ avsedda misshandeln och grov misshandel är i praktiken ofta svår att draga. Bemärkas bör, att t.ex. ett uppsåtligt förorsakande av svår kroppsskada, allvarlig sjukdom eller livsfara icke enbart för sig konstituerar grov misshandel; för att en dylik skall föreligga erfordras nämligen att misshandeln med beaktande av de omständigheter i sin helhet, vilka föranlett brottet och framgå av detsamma, bör anses grov. Å andra sidan kan ett uppsåtligt förorsakande av en i $5 \S$ avsedd kroppsskada eller sjukdom föranleda, att gärningsmannen dömes för grov misshandel, för så vitt förorsakandet skett under sådana förhållanden att misshandeln med beaktande av stadgandet $\mathrm{i}$ $6 \S$ bör anses grov. Ett stadgande om lindrig misshandel ingår slutligen i ifrågavarande kapitels $7 \S$. Dylik föreligger, om gärningen åstadkommer enbart fysisk smärta utan att härtill ansluter sig kroppsskada eller sjukdom eller om gärningen innebär handgriplighet eller annat fysiskt våld utan att åstadkomma någon av nyssnämnda påföljder (sagda betänkande). - I förevarande rättsfall hade gärningsmannen vid misshandelns förövande icke avsett åstadkommande av svår kroppsskada men det ansågs att han bort räkna med denna effekt. Gärningsmannen dömdes för uppsåtlig misshandel och vållande av kroppsskada, begångna i en gärning. Vållande av kroppsskada eller sjukdom, som icke är ringa, är straffbelagt enligt 21 kap. $10 \S$ strafflagen.

3) Fullgörandet av skadeståndsplikt såsom villkor för åtnjutande av anstånd med straffverkställigheten. Jämlikt $3 \S 2 \mathrm{mom}$. lagen angående villkorlig straffdom 20/6 1918 kan domstol så- 
som villkor för åtnjutande av anstånd med straffverkställigheten förelägga den dömde att inom viss tid fullgöra sin skadeståndsplikt, såframt han prövas vara i stånd därtill. Åsidosätter den dömde fullgörelsen av honom förelagd skadeståndsplikt bör domstolen jämlikt $5 \S 4$ mom. samma lag, såframt målsäganden anmäler därom före prövotidens utgång, förklara att straffet skall gå i verkställighet. Domstolen kan dock fritaga den dömde från nämnda villkor, där han gör sannolikt, att han av omständigheter, som ej skäligen kan tillräknas honom, varit urståndsatt att gottgöra skadan. I förstnämnda lagrum avsett föreläggande torde förekomma rält sällan i praxis.

6. På åtal av allmän åklagare och målsäganden fann HR utrett, att A $19 / 11971$ i Naskarla by av Pemar kommun uppsåtligen genom kvävning dödat B. För den skull och då omständigheterna vid gärningens begående bör anses ha varit synnerligen förmildrande dömde HR med stöd av 21 kap. $1 \S 1$ mom. strafflagen A för under dylika omständigheter förövat dråp till tukthus i 5 år. Åklagaren sökte ändring. - HovR: enär dråpet icke kunde anses ha begåtts under synnerligen förmildrande omständigheter, dömdes A för den honom tillräknade gärningen till tukthus i 8 år. Åklagaren och A sökte ändring. — HD: enär av omständigheterna i målet ej kunde slutas, att A, vilken vid samlag med $\mathrm{B}$ med våld bundit en tyglapp för dennas mun, skulle uppsåtligen dödat $\mathrm{B}$, men A stannade till last, att han sålunda uppsåtligen genom kvävning förorsakat $B$ ett av andningens hämmande uppkommet livsfarligt tillstånd, varav B dött, och döden sålunda bör anses hava föranletts av A:s grova ovarsamhet, och då även den förövade misshandeln med beaktande av livsfaran, gärningssättets råhet och av andra av brottet framgående omständigheter $\mathrm{i}$ sin helhet bör anses grov, dömdes A med stöd av 21 kap. 6 och $9 \S \S$ samt 7 kap. $1 \S$ sagda lag för grov misshandel och grovt dödsvållande, begångna i en gärning, till tukthus i 7 år och 10 månader. - Tvenne ledamöter fastställde HovR:s utslag. HD: utslag 7/10 1971.

Ifrågavarande brott begicks efter det lagen om ändring av strafflagen 14/7 1969 trätt i kraft. I anledning av detta rättsfall hänvisas endast till vad i föregående rättsfall framhållits angående misshandelsbrotten. Förorsakande av annans död genom grov vårdslöshet eller oaktsamhet är kriminaliserat i 21 kap. $9 \S$ strafflagen.

\section{Förelåg hemfridsbrott?}

7. På åtalan av allmän åklagare och målsäganden A förklarade RR utrett, att studeranden B åren 1967 och 1968 i Helsingfors stad genom att vid flere tillfällen fästa av honom speciellt för 
ändamålet förfärdigade tekniska apparater vid väggen av sin bostad kommit att intränga $\mathrm{i} A$ :s angränsande våning sålunda, att han tydligt kunnat avlyssna $\mathrm{i}$ sagda våning passerade förehavanden, vilka anslöto sig till A:s privatliv och vilka eljest icke kunnat avlyssnas. Dessa förehavanden hade B upptagit på band och därefter föredragit bandupplagningarna för andra personer som tidsfördriv. För den skull och då $\mathrm{B}$ genom att avsiktligen vidtaga särskilda åtgärder för att förverkliga omförmälda avlyssnande utan antagbart och lagligt skäl inträngt i A:s privatliv och sålunda kränkt det A tillkommande privata rättsskydd, som ingår i den medborgare tillförsäkrade hemfriden, bötfällde RR med stöd av 24 kap. $1 \S 1$ mom. och 7 kap. $2 \S$ strafflagen B för fortsatt hembridsbrott. Åklagaren och B sökte ändring. - HovR ansåg visserligen utrett, att $B$ i sin våning använt förstärkningsapparater för att avlyssna från grannen $\mathrm{A}$ : $\mathrm{s}$ våning nående ljud, vilkas avlyssnande eljest ej varit möjligt, samt medelst förstärkare upptagit på band de ljud han avlyssnat och tillåtit andra personer att avlyssna sagda bandupptagningar samt sålunda kränkt A:s rätt att erhålla skydd för sitt privatliv, men enär B:s omförmälda förfarande icke kunde anses såsom en i det av RR åberopade lagrummet eller eljest enligt lag straffbelagd gärning, ogillade HovR, med förkastande av RR:s utslag, åtalet. Åklagaren ansökte om prejudikatdispens. - HD biföll ansökningen och fastställde HovR: s utslag. II 101/1971.

Detta rättsfall har väckt uppmärksamhet och har, såsom nedan skall framhållas, föranlett lagstiftaren att komplettera strafflagens stadganden om hemfridsbrottet. Om störande av privat hemfrid stadgas i 24 kap. $1 \S$ strafflagen, vilket lagrum ännu är gällande i sin ursprungliga lydelse: „Hvar, som, utan laga skäl, emot annans vilja, intränger i hans hemvist, vare sig rum, hus, gård eller fartyg antingen han dem sjelf eger eller har lof eller lega för sig, eller utan fog underlåter att på tillsägelse derifrån aflägsna sig, eller utan skälig anledning insmyger sig dit eller gömmer sig der undan, straffes för hemfridsbrott - - -." Med uttrycken intränga samt insmyga eller gömma sig i annans hemvist har lagstiftaren tydligen avsett, att den, som kränker hemfriden på i lagrummet anfört sätt personligen överskridit gränsen för den kränktes hemvist. Lagens ordalydelse talar härför och det synes även som om Forsman, vilken väl bäst kände till strafflagens förarbeten, i sin kommentar till sagda lag skulle tolkat ifrågavarande lagrum sålunda (De särskilda brotten 1917 II s. 172 ff). Denna tolkning har i förevarande rättsfall tydligen omfattats av HovR och HD, medan RR åter torde tillämpat stadgandet i nyssnämnda lagrum ex analogia på det i rättsfallet omförmälda avlyssnandet; RR:s ståndpunkttagande vore ur den dömdes synpunkt ett analogislut in malam partem. För HovR:s och 
HD: s ståndpunkt talar även den omständigheten, att genom en lagstiftningsakt av år 1938 infogades i 24 kap. strafflagen en ny 3a §, enligt vilken den, som av illvilja eller självsvåld stör annans hemfrid genom oljud eller annat oväsende eller ock i uppenbar avsikt att störa annan orsakar uppringning till honom i telefonapparat, gör sig skyldig till straffbar handling; dessa sistnämnda handlingsmodi företagas väl of tast utanför den kränktes hemvist och deras särskilda kriminalisering hade varit onödig om de hade ansetts kunna subsumeras under stadgandet i 24 kap. 1 §. HD har i ifrågavarande rättsfall emellertid uttalat, att $\mathrm{B}$ genom omförmälda avlyssnande gjort sig skyldig till en handling, som, om den ock icke är av kriminell natur, dock kränker A:s rätt att erhålla skydd för sitt privatliv och sålunda är rättsstridig. Det är fråga om en kränkning av den s.k. intimiteten. I finsk doktrin har ansetts, att den, vars berättigade intimitetsintresse avsiktligen eller av vårdslöshet kränkts, äger rätt att utverka förbudsdom och att erhålla skadestånd (Kivimäki-Ylöstalo, Lärobok i Finlands civilrätt s. 17, Hakulinen, Obligationsrätt I 1962 s. 350 samt Melander, Intimiteetin oikeussuojasta Lakimies 1964 s. 785 ff). Av handlingarna i detta mål framgår, att A yrkade endast B:s fällande till straff. Hade han t. ex. yrkat ersättning för liden skada, matcriell eller immateriell, är det troligt, att domstolarna i detta sammanhang upptagit detta yrkande till prövning (Se rättsfall 9 ). — Ifrågavarande rättsfall föranledde justitiekansler att avlåta en skrivelse till justitieministeriet, i vilken han med hänvisning till sagda $H D$ avgörande framhöll, att däri omförmälda förfarande vore ägnat att i allvarlig mån kränka den enskilda individens intimitet, varför ett dylikt och därmed liknande intränganden i den enskilda individens rättssfär borde kriminaliseras; detta vore särskilt motiverat nu, då teknikens utveckling erbjuder ständigt tilltagande möjligheter att ingripa i medmänniskors privatliv och kränka deras rätt att leva sitt liv i fred och hemlighålla sina enskilda angelägenheter (Defensor Legis 1972 rättsfallsavd. s. 18). Genom lagen om komplettering av strafflagen med vissa straffstadganden angående kränkande av skyddet för privatlivets helg 11/7 1972, som träder i kraft 1/9 1972, fogades så till 24 kap. strafflagen en ny 3 b $\S$. Enligt detta lagrum straffas för olovlig avlyssning den som olovligen med teknisk apparat avlyssnar eller upptar vad som sker på plats eller inom område, som avses i 24 kap. 1 §, samt för olovlig observation den som olovligen med teknisk apparat iakttar eller avbildar person, som befinner sig på plats eller inom område, som avses i sagda paragraf. 


\section{Ärekränkning.}

8. A och $B$ anförde vid $R R$, att sedan $C$ tillsänt $D$, vilken verkade såsom ombudsman för en förening, en lista för uppgörande av en förteckning, som föreningen vid 29/3 1967 hållet årsmöte beslutat upprätta över dåliga kunder, i vilken lista han antecknat A:s och B:s namn i gruppen „storbrottslingar", hade D och E, D 27/4 1967 i föreningens namn sänt åt ungefär 30 av föreningens medlemmar ett cirkulär, till vilket närslutits såsom bilaga en förteckning, däri A och B antecknats såsom personer, vilka på brottsligt sätt förorsakat förlust åt föreningens medlemsaffärer, och E i egenskap av föreningens ordförande godkänt avsändandet av sagda förteckning i cirkulär åt föreningsmedlemmarna. För den skull och då den omständigheten, att A och $\mathrm{B}$ på omförmält sätt omnämnts såsom brottslingar inverkat menligt på den affärsverksamhet de idkade, yrkade A och B, i det de yrkade att även $\mathrm{C}$ skulle ådömas straff, D:s och E:s fällande till straff för emot bättre vetande gjord offentlig smädelse. — RR förklarade utrett, att vid förenämnda lagligen sammankallade och beslutföra föreningsmöte hade beslut fattats om uppgörandet av en förteckning $\mathrm{i}$ två delar över sådana personer, vilka föreningsmedlemmarna veterligen var dåliga kunder, varvid till första gruppen skulle hänföras de personer, vilka på ett brottsligt sätt förorsakat medlemsaffärerna förlust, och till andra gruppen de så kallade dåliga betalarena och att medlemmarna skulle angående sagda kunder kontinuerligt sända noggranna personuppgifter åt föreningens ombudsman, varjämte beslutits, att uppgiftens avsändare ensam svarade för riktigheten av den uppgift han givit, att i förteckningen, som skulle tillställas medlemmarna, icke skulle antecknas varifrån uppgifterna ledde sitt ursprung, utan att varje medlem av föreningens ombudsman skulle vid behov erhålla vetskap om den medlem som meddelat uppgiften, att förteckningen icke finge utlånas eller förevisas för person, som icke tillhörde föreningen samt att saken skulle i alla avseenden handhavas förtroendefullt. I anledning av föreningens beslut hade $C$ tillsänt $D$, vilken verkade såsom föreningens ombudsman och fungerat såsom sekreterare vid sagda möte, omförmälda, av honom uppgjorda lista, varefter föreningen, vars ordförande då var $\mathrm{E}$, tillsänt inemot 30 av sina medlemmar i käromålet nämnda cirkulär, vari bl. a. redogjorts för de orsaker som lett till sagda beslut och meddelats att man helt konfidentiellt skulle påbörja publiceringen av en förteckning över dåliga kunder samt redogjorts för beslutets praktiska förverkligande med särskilt omnämnande, att mottagarena icke finge dupplicera förteckningen och utdela denna åt affärer, som icke tillhörde föreningen, utan att den skulle förbliva en föreningens inre angelägenhet. Såsom bilaga till cirkuläret hade bifogats en förteck- 
ning, vari vid de personers namn, vilka på ett brottsligt sätt förorsakat medlemsaffärerna förlust, nämnts bl. a. A:s och B:s namn. För den skull och då D icke visats vid avsändandet av sagda cirkulär med bilagor hava avvikit från föreningsmötets beslut, vars bringande $\mathrm{i}$ verkställighet ålegat D såsom föreningens ombudsman, och enär icke utretts, att $\mathrm{E}$ skulle gjort sig saker till vad honom tillvitats, ogillade RR, i det den fällde $\mathrm{C}$ till straff, de mot D och E gjorda yrkandena. A och B sökte ändring. - HovR: enär D och $\mathrm{E}$ i sina omförmälda befattningar, $\mathrm{D}$ genom att underskriva och $\mathrm{E}$ genom att godkänna ifrågavarande cirkulär, i vars bifogade förteckning A och B på grund av den av $\mathrm{C}$ givna uppgiften påbördats handlingar, vilka kunnat vara menliga för deras näring, avsiktligen kränkt $A$ och $B$, dock icke mot bättre vetande och ej heller offentligen, enär sagda förteckning tillsänts endast föreningens medlemmar och därtill med meddelande, att de uppgifter, som ingick i förteckningen icke finge yppas för personer, vilka icke tillhörde föreningen, för den skull och då till stöd för sagda tillvitelser icke anförts sannolika skäl dömde HovR med stöd av 27 kap. $2 \S 1$ mom. och 7 kap. $1 \S \mathrm{D}$ och $\mathrm{E}$ för två smädelser, begångna i en gärning, till bötesstraff. D och E anhöll om prejudikatdispens. - HD biföll ansökningen och prövade målet; och enär D och E medelst ifrågavarande, vid föreningens årsmöte fattade beslut icke kunnat fritaga sig från det straffrättsliga ansvar, som ansluter sig till cirkulärets avsändande och cirkuläret avsänts på D:s och E:s föranstaltande utan att de därförinnan förvissat sig om sanningsenligheten av de av $\mathrm{C}$ om A och B givna oberättigade uppgifterna, förklarade HD på dessa och i övrigt på av HovR anförda grunder skäl icke föreligga till ändring $\mathrm{i}$ det slut, vartill HovR i sitt utslag kommit. — II 77/1971.

\section{Om försnillning.}

9. På yrkande av allmän åklagare förklarade HR utrett, att jordbrukaren A vintern 1969 i Korpi by av Metsämaa kommun, sedan han 22/10 1968 sålt åt Loimaa andelsaffär 7,000 kilogram havre, vilken sädesmängd förblivit i A:s besittning, och följande dag lyft spannmålens pris $2520 \mathrm{mk}$, underlåtit att överlåta åt andelsaffären ifrågavarande sädesmängd och använt denna för eget behov och sålunda utan laga rätt tillägnat sig densamma, varför HR med stöd av $29 \mathrm{kap} .1 \xi 1 \mathrm{mom}$. strafflagen bötfällde A för försnillning och ålade honom att utbetala i skadeersättning åt andelsaffären $2.520 \mathrm{mk}$ jämte laga ränta. A sökte ändring. HovR: ej annan ändring än att bötesstraffet nedsattes. A sökte ändring. - HD ansåg icke utrett, att ifrågavarande spannmålsmängd, vilken med andelsaffärens tillstånd förblivit i A:s lager, skulle avskiljts från A tillhörig övrig havre, för den skull och 
då A genom att sedermera använda havren för annat ändamål icke gjort sig saker till straffbar handling, men andelsaffären till följd av A:s förfarande ägde rätt att av A få tillbaka det pris den erlagt åt honom för havren, ogillade HD det mot A riktade straffanspråket, men lät vid HovR:s utslag bero såvitt A förpliktats att utbetala åt andelsaffären ersättning för havrens pris jämte ränta. - En ledamot ansåg icke utrett, att ifrågavarande havremängd skulle avskiljts från i A:s lager varande övrig havre och sålunda övergått i andelsaffärens ägo och att A genom att använda spannmålsmängden för eget behov sålunda skulle tillägnat sig i sin värjo varande främmande egendom, varför sagda ledamot ogillade straffanspråket och frikände $\mathrm{A}$ från det honom ådömda straffet och frikallade A från den honom på kriminell grund ådömda ersättningsskyldigheten. En ledamot fastställde HovR:s utslag. II 33/1971.

1) Allmänna anmärkningar. De lägre instanserna likasom en ledamot av HD ansåg tydligen utrett, att föremål för överlåtelsen var en viss, individuellt bestämd mängd havre; vid tidpunkten för överlåtelsen hade äganderätten till sagda havremängd övergått till andelsaffären. HD:s majoritet utgick åter från att A förbundit sig att från sitt havrelager leverera åt andelsaffären 7.000 kilogram; då A sedermera använde sagda lager för eget behov, begick han icke en straffbar handling; hade ifrågavarande 7.000 kilogram avskiljts för andelsaffärens räkning och A därefter tillgripit den avskiljda havremängden hade försnillning däremot förelegat.

2) Ehuru straffanspråket ogillats har ersättning likväl utdömts. Av intresse är att HD, ehuru den ogillade straffanspråket, likväl utdömde skadeersättning. Grunden för utdömandet är alltså privaträttslig. Tidigare utgick man i doktrinen och även rätt allmänt i domstolspraxis från att domstol icke ägde i anledning av en väckt straff- och skadeståndstalan bifalla skadeståndsanspråket, då strafftalan ogillats. Om brott icke förelåge, kunde man nämligen principiellt icke tänka sig en privaträttslig grund för godkännande av skadeersättningskravet. I slutet av 1940 talet begynte dock praxis förändras. I rättsfallet II 310/1948 utdömde HD sålunda skadestånd, ehuru den ogillade strafftalan. I sitt verk „Rikosprosessilain asiallisesta sovellutusalasta“ redogör Aalto för ett antal opublicerade HD avgöranden från 1950 talet, i vilka $H D$, dock efter omröstning, utdömde skadestånd, ehuru straffanspråken ogillades (s. 164 not 7 a). I rättsfallet II 114/ 1961 intog HD sistnämnda ståndpunkt. I rättsfallet II 14/1969 ogillade HD framställt straffyrkande, enär den åtalade icke befunnits skyldig till straffbar gärning, men prövade dock i målet gjort skadeståndsanspråk, som grundats på den åtalades rättsstridiga förfarande. De tvenne sistnämnda avgörandena voro en- 
hälliga. I nu ifrågavarande rättsfall ogillade en ledamot straffanspråket, men utdömde likväl icke skadestånd, ehuru skadans storlek var utredd. För utdömande av ett skadeståndsanspråk har uttalat sig bl. a. Alanen (Defensor Legis 1932 s. 421) och Palme (FJFT 1946 s. $295 \mathrm{ff}$ ), vilken framhåller de skälighetssynpunkter och praktiska fördelar ett dylikt utdömande medför. Tirkkonen, som i första upplagan av sitt verk om Finlands straffprocessrätt intog den äldre ståndpunkten (Suomen rikosprosessioikeus I 1948 s. 92) har i andra upplagan av sagda verk (Suomen rikosprosessioikeus I $1969 \mathrm{~s} .73$ f), enär till stöd för åsikten att domstol i anledning av väckt straff- och skadeståndstalan äger bifalla skadeståndsanspråket ehuru strafftalan ogillas, för så vitt gärningen enligt privaträttsliga regler grundar ersättningsskyldighet, kan anföras beaktansvärda synpunkter, omfattat sagda åsikt.

3) Ny lag. Lagen om ändring av strafflagen 30/6 1972, som träder i kraft 1/9 1972, har ändrat bl. a. sagda lags stadganden om försnillningsbrottet. En kort redogörelse härför erbjuder måhända intresse. 29 kap. 1 § strafflagen lydde: ,Tillägnar man sig utan laga rätt, annans lösegendom, vilken man har i sin värjo, straffes för försnillning _- - - “. Med annans lösegendom har man förstått annan tillhörig egendom, speciessak eller särskilt för sig förvarade mängdsaker. Enligt sagda $\S: \mathrm{s} 2 \mathrm{mom}$. dömdes den brottslige enligt en särskild strängare straffskala, om egendomen var den brottslige anförtrodd under lås, försegling, eller annat stängsel, eller bärgad undan uppror, fiende, brand, vattunöd, skeppsbrott eller annan sådan fara eller om omständigheterna eljest voro synnerligen försvårande. Numera benämnes brottet förskingring, men lagändringen avser icke att ändra de av tidigare lag omfattade normala brottskännetecknen för försnillning (Lagberedningens förslag till Regeringens proposition till Riksdagen med förslag till ändring av stadgandena om vissa förmögenhetsbrott och om skattebedrägeri; publikation n:o 81970 s. 12). Den nya lagen skiljer mellan grundbrottet förskingring (29 kap. $1 \S 1$ mom.), grov förskingring (29 kap. $2 \S$ ) samt lindrig förskingring (29 kap. 3 §). Begås förskingring med utnyttjande av för ändamålet oriktigt förda böcker eller av gärningsmannens ansvarsfulla ställning eller är synnerligen värdefull egendom eller större penningbelopp föremål för brottet och bör förskingringen i sagda eller övriga fall med beaktande av de omständigheter i sin helhet, vilka föranlett brottet och framgå av detsamma, anses grov, föreligger grov förskingring. Förhandenvaron av något av de i $2 \S$ särskilt uppräknade kvalificerade fallen konstituerar ännu icke grov förskingring; vid prövning av frågan huruvida förskingring bör anses grov eller icke skall domstolen nämligen såsom en helhet beakta de om- 
ständigheter, som lett till eller framgår av brottet. Bör förskingring åter, med beaktande av det tillgripnas värde eller de olovligen använda medlens belopp eller av andra omständigheter, vilka framgå av eller lett till brottet, anses ringa, föreligger enligt lagen lindrig förskingring. - En nyhet i finsk strafflagstiftning är att orättmätig användning av omhändertagna medel straffas såsom förskingring (försnillning). Jämlikt 29 kap. 1 § 2 mom. strafflagen i dess nya lydelse straffas nämligen för förskingring den som efter att på grund av uppdrag eller på annat sådant sätt i sin värjo ha fått medel, vilkas värde han skall redovisa för annan, för att skaffa sig själv ekonomisk fördel orättmätigt använder sagda eller i deras ställe komna medel och sålunda förorsakar, att redovisningsskyldigheten ej fullgöres. Här föreligger alltså en ulvidgning av det tidigare försnillningsbegreppet. Enligt de normala brottskännetecknen för försnillningförskingring skall föremålet för sagda brott ägas av annan. Frågan om äganderätten till föremålet avgöres enligt civilrättsliga regler; härvid har dock tolkningen av brottskännetecknen i fråga om penningar och överhuvud mängdsaker stött på svårigheter. Enligt civilrättsliga regler övergår mängdsaker i omhändertagarens ägo, när de sammanblandas med dennes tillgångar. Stadgandet om försnillning har tillämpats, såframt omhändertagaren varit skyldig att hålla den andras tillgångar åtskilda från sina egna; försnillning förelåg när omhändertagaren sammanförde de främmande medlen med sina egna i avsikt att tillägna sig egendomen. I praktiken ställde det sig emellertid of ta svårt att avgöra när dylik avsikt och skyldighet att hålla medel åtskilda från de egna medlen förelåg. I praxis förekom därför att man utvidgade försnillningsbegreppet utöver vad de civilrättsliga stadgandena förutsatte för att stadgandena om försnillning skulle kunna tillämpas på orättmätig användning av omhändertagna medel (förenämmda publikation s. 12; Finska domar i brottmål 1961-1969, årgång 1970, rättsfall 21). Med medel avses i 29 kap. $1 \S 2$ mom. i dess nya lydelse såväl penningar som andra mängdsaker. Sagda moment omfattar de fall, då handlingen icke riktar sig mot annan tillhörig speciessak eller särskilt för sig förvarade mängdsaker, för vilken handling straff utmätes enligt nämnda paragrafs 1 mom., utan mot den obligationsrättsliga redovisningsskyldighet, som uppstått genom att annans medel i civilrättslig mening genom sammanslagning blivit omhändertagarens egendom och vilken redovisningsskyldighet ej fullgjorts (nämnda publikation s. 13). I händelse omhändertagaren efter sammanslagningen av medlen i avsikt att berika sig använder de omhändertagna eller i deras ställe komna medel och sålunda förorsakar, att redovisningsskyldigheten ej fullgöres, gör han sig skyldig till förskingring; är avsikten med åtgärden åter att skada annan, 
kan gärningen måhända bestraffas såsom oredlighet. Enligt lagberedningens förslag och Regeringens proposition till Riksdagen skulle förskingring förelegat redan om någon medveten om att han äventyrade fullgörandet av sin redovisningsskyldighet i nyssnämnda avsikt använde uppburna eller i deras ställe komna medel (sagda publikation s. 13; Regeringens proposition N:o 23 till 1972 års Riksdag). Lagutskottet framhöll dock, att det of ta är svårt att vid rättegång leda $\mathrm{i}$ bevis förhandenvaron av ett dylikt äventyrande. Härav skulle följa, att det föreslagna stadgandet mestadels skulle tillämpas endast på de fall, i vilka den redovisningsskyldigas insolvens blivit utredd. Av denna anledning ansåg utskottet ändamålsenligt, att straffstadgandet angående förskingring skulle tillämpas endast på ett sådant oberättigat användande av annans medel, som förorsakat, att redovisningsskyldigheten ej fullgjorts (Lagutskottets betänkande n:o 4 vid 1972 års Riksdag); Riksdagen godkände utskottets ändringsförslag.

10. Allmän åklagare yrkade vid RR A:s fällande till straff för det denne $12 / 51969$ i Tammerfors stad tillgripit sin fader tillhöriga personbil. RR och HovR fällde A till straff för stöld. HD: enär A genom att tillgripa bilen, med beaktande av att denna tillhörde hans fader och att A fortfarande var bosatt i föräldrahemmet, gjort sig skyldig till bodräkt, men fadern icke anmält brottet till åtal och de lägre instanserna med hänsyn till stadgandena i 30 kap. $2 \S$ strafflagen och $18 \S$ förordningen om införande av strafflagen sålunda icke bort på åtal av allmän åklagare ådöma A straff för sagda brottsliga gärning, undanröjde HD de lägre instansernas utslag. II 14/1970.

I 30 kap. $1 \S$ strafflagen stadgas: ,Draga makar något undan hvarandra eller barn undan föräldrar, eller fosterbarn undan fosterföräldrar, eller sterbhusdelegare eller andre, som äro i samfäldt bo eller i bolag, undan boet eller bolaget; straffes den skyldige för bodräkt med böter _ - _.". Den i lagrummet kriminaliserade handlingen, undandragande, är, för så vitt det i detsamma förutsatta förhållandet mellan den brottslige och den förorättade icke föreligger, till sin karaktär försnillning, snatteri, stöld eller grov stöld. Då lagen använder ordet undandraga kan härav slutas, att om någon gör sig saker t. ex. till bedrägeri eller utpressning mot person, som står till honom i elt i sagda paragraf nämnt förhållande, den brottslige bör straffas för bedrägeri respektive utpressning. Den omständigheten, att lagen straffar mildare person, som gör sig saker till försnillning, snatteri, stöld eller grov stöld, för den händelse den förorätlade befinner sig till honom i sagda förhållande, torde bero dels på etiska skäl dels på att samäganderätt föreligger. Begås något av sagda brott av barn eller 
av fosterbarn är det etiska motivet enbart avgörande, ty någon samäganderätt föreligger ju då icke. Forsman framhåller, att det är familjens sedliga intresse lagstiftaren velat skydda genom att särskilja bodräkt från det tjuvska tillgreppet. En följd härav är — och detta har även framhållits i såväl teori som praxis att tillämpningen av förenämnda lagrum förutsätter, att barnen och fosterbarnen ännu stadigvarande vistas i föräldrahemmet. En tillfällig vistelse utom hemmet är icke å sak verkande. Av handlingarna i ifrågavarande mål framgår, att A tillfälligt vistades utom hemmet. I rättsfallet II 33/1955 ansåg HD, att en dotter, som varaktigt flyttat från föräldrahemmet, gjort sig saker till stöld, då hon tillgripit penningar av sin moder, som tillfälligtvis befann sig på besök hos henne. Bodräkt är ett målsägandebrott. Ett ovillkorligt åtalande skulle, såsom Forsman framhåller, då det är fråga om familjemedlemmar, medföra stora olägenheter; det skulle slita de sedliga band, som förena familjens särskilda medlemmar och därigenom i hög grad sätta familjens sedliga ändamål på spel.

\section{Rånartad utpressning.}

11. På åtalan av allmän åklagare förklarade RR utrett, att A $7 / 11971$ i Fredrikshamns stad i Fredrikshamns sparbanks huvudkontor, i avsikt att bereda sig nytta, genom att på ett vilseledande sätt med en om en riktig pistol påminnande leksakspistol hota bankens kassörska sålunda, att denna trodde sig vara i trängande livsfara, tvingat kassörskan att överlämna åt honom i bankens kassa befintliga penningar till ett belopp om 10.250 $\mathrm{mk}$, av vilken summa $317 \mathrm{mk} 2 \mathrm{p}$ icke återfåtts. För den skull och då A tidigare utstått direkt ådömt frihetsstraff under ett år dömde RR med stöd av 31 kap. $1 \S 1$ mom. och $4 \S 3$ mom. samt 6 kap. 1 \& strafflagen $\mathrm{A}$ för rånartad utpressning till tukthus $\mathrm{i}$ 2 år, förpliktade honom att utbetala åt banken i ersättning 317 mk 2 p jämte laga ränta samt förklarade leksakspistolen förbruten till statsverket. Åklagaren och A sökte ändring. - HovR: ej annan ändring än att det A ådömda straffet höjdes till tukthus i 3 år. A sökte ändring. — HD: ej ändring. II 60/1971.

Enligt finsk straffrätt föreligger rẳn då någon med våld å person eller med hot, som innebär trängande fara för liv eller hälsa, fråntager annan gods eller penningar i avsikt att utan laga rätt tillägna sig eller annan egendomen (31 kap. $1 \S 1 \mathrm{mom}$. strafflagen). Utpressning är för handen, då någon för att bereda sig eller annan nytta genom hot avtvingar annan fördel i egendom, vartill denne ej har laga rätt (31 kap. 4 \$ 1 mom.). Rån förutsätter alltså ett fråntagande, utpressning ett avtvingande eller att den för utpressning utsatte blir nödd att företaga en handling, som förbättrar utpressarens förmögenhetsläge. Om det i utpressningen ingående hotet innebär trängande fara för liv 
eller hälsa eller göres våld å person, föreligger åter rånartad utpressning (31 kap. $4 \S 3$ mom.). Gränsen mellan rån och rånartad utpressning är ofta svår att uppdraga, isynnerhet om vid sistnämnda förekommer våld å person. Ett i 31 kap. $4 \S 1 \mathrm{mom}$. avsett hot föreligger även om dess verkställande icke ens är möjligt blott hotet förefaller den, mot vilken det är riktat, såsom allvarligt menat så att det är ägnat att inverka på dennes beslut att företaga den handling, som förbättrar utpressarens förmögenhetsläge; å andra sidan bör gärningsmannen tro, att den för hotet utsatte antager, att hotet är allvarligt avsett. Denna ståndpunkt har intagits av finsk doktrin (Forsman, De särskilda brotten 1917 I s. 90 o. 359; Honkasalo, Suomen rikosoikeus, Erityinen osa 1,2 s. 110). - Av handlingarna i målet framgår, att A infann sig i bankkontoret omedelbart före det kontoret stängdes då alla kunder redan avlägsnat sig och i kontorslokalen endast befann sig kassörskan och en kvinnlig kontorist. A riktade sin av plast förfärdigade leksakspistol, som liknade en 7,65 kalibers pistol av märket Walther, mot kassörskan under utropet: ,pengarna hit". Denna, som icke kände till pistolers konstruktion, trodde att vapnet var en riktig, laddad pistol och överlämnade medan hotet hela tiden fortbestod och till följd av detta i tre skilda poster tidigare nämnda penningsumma åt $\mathrm{A}$, som därpå skyndsamt avlägsnade sig. Ur kassörskans synpunkt sett torde det utan tvivel varit fråga om ett hot, som innebar trängande fara för liv.

\section{Döljande av tjuvgods.}

12. Allmän åklagare yrkade vid RR A:s fällande till straff för det denne, sedan $\mathrm{B}$ natten mot 25/6 1970 från C:s bil tillgripit en denne tillhörig kamera och pantsatt denna åt Helsingfors PantAktiebolag mot ett lån om $50 \mathrm{mk}$, i slutet av sagda månad emottagit av B det vid förpantningen åt denne utgivna kviltot, fastän A, utan att han själv varit delaktig i tillgreppet, var medveten om att kameran var åtkommen genom stöld. RR fann A vara saker till vad honom tillvitats och dömde A, som utstått direkt ådömt frihetsstraff över ett, men dock icke i tre år, med stöd av 32 kap. $1 \S$ och 6 kap. $2 \S$ strafflagen för döljande av tjuvgods såsom återfallsförbrytare till fängelsestraff och förpliktade honom, enär bolaget nödgats utan lösen utgiva kameran åt $\mathrm{C}$, att solidariskt med $\mathrm{B}$, som i målet även ådömts straff, utbetala i ersättning åt bolaget $50 \mathrm{mk}$. A sökte ändring. - HovR nedsatte fängelsestraffet. - HD: ej annan ändring än att, enär A genom att emottaga av B ifrågavarande pantkvitto icke förorsakat bolaget skada, frikallades A från att erlägga åt detta sagda belopp, som sålunda skulle ersättas av B allena. II 50/1971.

I 32 kap. $1 \S$ strafflagen stadgas: „Den, som gömmer, köper, 
tillbyter sig, såsom gåfva eller pant emottager, föryttrar, ändrar eller omarbetar egendom, som han vet vara åtkommen genom snatteri, stöld, rån eller utpressning, utan att han sjelf varit delaktig i brottet, straffes för döljande af tjufgods — - “. Kan nu detta brott begås endast beträffande sådan egendom, vilken omedelbart åtkommits genom snatteri, stöld, rån eller utpressning eller eventuellt även med hänsyn till egendom, vilken erhållits i utbyte $\mathrm{i}$ den omedelbart genom tillgreppsbrottet åtkomna egendomens ställe? HD har i nu ifrågavarande rättsfall biträtt sistnämnda åsikt. Denna ståndpunkt har i doktrinen omfattats av Forsman, som framhållit - med hänvisning till paragrafens uppkomsthistoria - att ordet egendom icke kan tolkas så inskränkt, som paragrafens ordalag möjligen kunde giva vid handen, nämligen att brottet gäller endast den egendom, som omedelbart blivit genom tillgreppsbrottet åtkommen. Man kan svårligen i sagda hänseende uppställa någon bestämd regel, utan avgörandet får bero på domarens prövning i det enskilda fallet. I allmänhet kan man dock säga, att även om den genom brottet åtkomna egendomen icke i sin omedelbara form utgör föremål för döljande av tjuvgods, kan 32:1 tillämpas i det fall, att tjuvgömmaren förövat handlingen under medvetande om att densamma är ägnad att i sin mån undanhålla egendomen den rättmätiga ägaren (De särskilda brotten 1917 I s. 530 ff). I förevarande fall hade $\mathrm{A}$ genom pantkvittot erhållit dispositionsmakt över kameran, som han ju kunde utbekomma från pantlånekontoret genom att uppvisa kvittot. Sundström-Salmiala ansluter sig till Forsmans åsikt och framhåller, att lagrummets ordalydelse torde språkligt kunna tolkas så, att föremål för tjuvgömmeri är egendom, som åtkommits medelst i lagrummet nämnd tillgreppshandling oberoende av om egendomen är identisk med föremålet för tillgreppshandlingen eller ej; ur kriminalpolitisk synpunkt vore Forsmans åsikt att föredraga (Defensor Legis 1946, rättsfallsavdelningen s. 25 not 1). SundströmSalmiala hänvisar även till ett rättsfall (HD Utslag 1922 meddelande n:o 117), av vilket man torde kunna sluta sig till, att HD i omförmälda avseende då var av samma åsikt som i nu ifrågavarande rättsfall. I doktrinen har även andra meningar uttalats. Serlachius framhåller sålunda, att endast för så vitt föremålet för tillgreppsbrottet varit en mängdsak och denna utbytts mot en mängdsak av samma slag kunde köp, gömmande o.s. v. av den tillbytta mängden anses för döljande av tjuvgods (Suomen rikosoikeuden oppikirja 1926 II 2 s. 254). Honkasalo anser, att endast den sak, som omedelbart varit föremål för tillgreppsbrottet, kan utgöra föremål för döljande av tjuvgods (Suomen rikosoikeus Erityinen osa I 2 s. $273 \mathrm{ff}$ ). Omnämnas bör rättsfallet II 3/1968: A hade förtärt av B honom veterligen med 
genom bedrägeri åtkomna penningar inköpta alkoholdrycker, utan att vara delaktig i bedrägeriet. A ansågs icke ha gjort sig saker till olovlig befattning med gods, som åtkommits genom brott.

\section{Mordbrand m.m.}

13. På åtalan av allmän åklagare och målsägande förklarade HR utrett, att före detta handlanden A 24/5 1968 i Kuivaniemi by av Kuivaniemi kommun, i avsikt att bereda sig orättmätig fördel i egendom, uppsåtligen satt i brand sin ägande bl. a. i försäkringsbolaget B mot eldfara försäkrade butiksbyggnad, vars varulager och inventarier likaledes voro försäkrade i sagda försäkringsbolag, med påföljd, att en del av byggnaden och även en del av däri förvarad egendom förstördes vid eldsvådan, vilken antändning, med beaktande av att byggnaden emedan den var uppförd av bräder och till följd av däri befintlig lätt antändbar egendom var utsatt för snabb spridning av elden, inneburit, för så vitt branden icke, såsom skett, i tid begränsats, uppenbar fara, förutom för några andra i närmaste omgivning belägna byggnader, för en på ett avstånd av knappt 10 meter från ifrågavarande byggnad beläget och en sparbank tillhörigt rappat affärsoch boningshus av bräder samt för en på ett avstånd av 5 meter från omförmälda byggnad belägen förrådsbyggnad. För den skull och då A vid begåendet av sagda gärning saknat förståndets fulla bruk, dömde HR med stöd av 34 kap. 4 § 1 och 3 mom., 36 kap. $2 \S 1$ mom., 3 kap. $2 \S$ och $4 \S 1$ mom. samt 7 kap. $1 \S$ strafflagen A för i dylikt tillstånd förövade mordbrand och försäkringsbedrägeri, begångna i en gärning, till fängelse i 2 år samt förpliktade A att utbetala vissa ersättningar. A sökte ändring. HovR: nedsatte straffet till fängelse i 1 år och 6 månader. A sökte ändring. - HD: ej ändring. II 56/1971.

I detta rättsfall intresserar främst brottet mordbrand. Benämningen mordbrand är en rättshistorisk reminiscens. Den vilar på den gamla uppfattningen, att brottet åtminstone i sin svåraste gestalt går ut på att beröva en människa livet och har bibehållits i finsk strafflag, ehuru de kännetecken, som hänföra sig till brottet mord icke ingå i brottet mordbrand ens i det fall, där detta förutsättes innebära fara för människoliv (Forsman: De särskilda brotten 1917 II s. 337). Om uppsåtlig mordbrand stadgas i 34 kap. strafflagen, som med arseende å den egendom, som utgör föremål för brottet, skiljer mellan tre slag av dylik brand. Om den första kategorin stadgas i $1 \S 1$ mom. av sagda kapitel. Detta lagrum straffbelägger förorsakande av brand å hus, byggnad, fartyg eller annat, som tjänar människor till boning, eller där människor å tid, då gärningen begås, pläga uppehålla sig eller där brandanstiftaren veterligen någon finnes; härvid är det 
till fyllest, att en abstrakt fara föreligger, ingen behöver på grund av branden verkligen ha råkat i fara. I sagda paragrafs 3 mom. stadgas dock, att för den händelse den antända egendomen var gärningsmannen själv tillhörig och antändningen ej innebar fara för annans liv, hälsa eller egendom, straff för mordbrand icke äger rum. För att antändning av gärningsmannen själv tillhörig egendom, som avses i nämnda paragrafs 1 mom., skall vara straffbelagd bör antändningen hava åstadkommit en verklig, konkret fara för annans liv, hälsa eller egendom. I 2 § kriminaliseras åter förorsakande av brand å vissa i detta lagrum nämnda, mera betydande offentliga byggnader eller å byggnad, där ämbetsrum finnes eller där offentlig samling av böcker, handskrifter o. s. v. förvaras. Föremål för det tredje slaget av mordbrand är jämlikt $4 \S 1 \mathrm{mom}$. bl. a. hus, byggnad eller fartyg i andra fall än i 1 och $2 \S \S$ nämnes. I $4 \S 3 \mathrm{mom}$. stadgas, att för så vitt det i brand satta var gärningsmannen själv tillhörigt och antändningen ej innebar uppenbar fara för annans liv eller hälsa eller för föremål, som i 1 eller $2 \S$ nämnes, eller för annan tillhörig egendom, som i $4 \S 1$ mom. säges — alltså för föremål, som kunna utgöra objekt för mordbrand - föreligger ej detta brott. Att observera är nämligen, att begreppet egendom i $1 \S$ $1 \mathrm{mom}$. avser egendom överhuvud, medan med egendom i 4 § 3 mom. avses dylik, som kan utgöra föremål för mordbrand. Stadgandet i 4 § 3 mom. förutsätter, såsom stadgandet i 1 § 3 mom., en verklig, konkret fara. Den antända butiksbyggnaden var en i 4 § 1 mom. avsedd byggnad. Av handlingarna i målet framgår, att den var belägen $i$ centrum av Kuivaniemi by. A hade $\mathrm{i}$ avsikt att uppbränna sin ifrågavarande egendom kastat en brinnande cigarettstump i en i butiksbyggnaden befintlig, bl. a. fotogennedsölat papper innehållande papplåda, i vars närhet fanns lätt antändbar egendom. Sedan pappret antänts spridde sig elden snabbt och inom c. 15 minuter trängde rök ut genom byggnadens tak. Innan den tillkallade brandkåren var redo för släckning sågs eldslågor på taket. Vinden, som visserligen var svag, blåste i riktning mot det på ett avstånd av c. 10 meter från butiksbyggnaden belägna, tidigare nämnda affärs- och boningshuset, som började evakueras. Brandmanskapet avstyrde dock eldens spridning. Av det framhållna framgår, att av branden en uppenbar, konkret fara förelåg för de invid butiksbyggnaden belägna byggningarna, av vilka affärs- och boningshuset bör hänföras till i 1 \$ $1 \mathrm{mom}$. avsedda byggnader och förrådsbyggnaden till byggnader, som omnämnas i $4 \S 1 \mathrm{mom}$. - Om försäkringsbedrägeri stadgas i 36 kap. $2 \S$ strafflagen; detta brott föreligger om någon i avsikt att bereda sig eller annan orättmätig fördel i egendom bl. a. sätter i brand egendom, vilken är försäkrad mot eldfara. 


\section{Brytande mot bestämmelse, som är föreskriven till skydd för upphovsrätt.}

14. Allmän åklagare anförde vid RR, att författaren Arvo Salo i sitt i början av år 1966 i Helsingfors utgivna verk „Lapualaisooppera“ („Lappo-operan“), vilket såsom sångspel gått över scenen förutom i sagda stad även på många andra orter i Finland, utan kaptenens i avsked Artturi Vuorimaas tillstånd och utan att angiva källan i oförändrat skick intagit en avsevärd del eller ungefär 150 rader av Salos 1.700 rader omfattande verk från det av Vuorimaa författade och år 1931 publicerade verket „Kolme kuukautta Kosolassa“ („Tre månader i Kosola gård“). Dylika citat voro bl. a. skildringarna av den sydösterbottniska folkkaraktären, folket på Torvrökens slätter, Lappo å och Kosola gård. Därjämte hade Salo i sitt verk, vari förekom en Artturi Vuorimaa benämnd person, förändrat Vuorimaas verk på ett sätt som nedsatte dettas litterära värde samt g.jort Vuorimaas verk tillgängligt för allmänheten i en form som kränkte Vuorimaa genom att återgiva från Vuorimaas verk plagierade delar i sådana sammanhang, att läsaren av Vuorimaas yttranden fick en förvrängd uppfattning om de syftemål Vuorimaa i sitt verk framställt såsom sina egna samt såsom utmärkade för den av honom skildrade folkrörelsen och idériktningen. För den skull yrkade åklagaren, att Salo skulle fälles till straff för brytande mot de bestämmelser, som givits till skydd för upphovsrätten. Vuorimaa förenade sig i egenskap av målsägande om åtalet samt yrkade därjämte, att Salo måtte förpliktas att till honom utgiva vederlag för det denne på i åtalet nämnt sätt utnyttjat hans verk. - RR fant utrett, att Salo visserligen i sitt verk „Lapualaisooppera“ från Vuorimaas verk „Kolme kuukautta Kosolassa“ intagit talrika citat, men enär Salo i sitt verk använt sig av dessa på ett sådant sätt, att han åstadkommit ett nytt och självständigt verk, förkastade RR med stöd av $4 \$ 2 \mathrm{mom}$. lagen om upphovsrätt till litterära och konstnärliga verk $8 / 71961$ de i målet gjorda yrkandena. - HovR, varest åklagaren och Vuorimaa sökte ändring, fann utrett, att Salo i sitt ifrågavarande verk av Vuorimaas verk intagit citat $\mathbf{i}$ så hög grad, att detta förfarande, då Salo icke erhållit tillstånd därtill av Vuorimaa och ej heller i sitt verk omnämnt Vuorimaas bok, borde anses såsom stridande mot god sed, men utredning saknas om att Salo eljest skulle brutit mot de bestämmelser som givits till skydd för upphovsrätten, varför HovR med stöd av $14 \S 1$ mom., $56 \S 1$ mom. och $57 \S 1$ mom. i förenämnda lag dömde Salo för brytande mot de bestämmelser som föreskrivits till skydd för upphovsrätten till 20 dagsböter á $15 \mathrm{mk}$ eller att erlägga i böter $300 \mathrm{mk}$ samt förpliktade honom att utbetala åt Vuorimaa såsom skäligt vederlag för utnyttjandet av dennes verk $1.000 \mathrm{mk}$. Salo anhöll om 
prejudikatdispens. - HD beviljade Salo fullföljdstillstånd, prövade målet och fann däri utrett, att Salo i sitt ifrågavarande verk låtit en Artturi Vuorimaa benämnd person och i mindre utsträckning även en del andra personer i egenskap av anhängare av den så kallade lapporörelsen framställa repliker, vilka, förutom några betydelselösa ändringar i ordalydelsen, utgjorde citat från Vuorimaas omförmälda verk, samt att citaten utan Vuorimaas tillstånd och utan att angiva källan intagits i Salos verk i det omfång, som framgick av åtalet. Enär emellertid Salos verk måste anses vara ett nytt och självständigt verk, vilket i egenskap av ett till skönlitteraturen hänförbart skådespel hör till en annan litteraturart än Vuorimaas verk, som till sin natur var ett memoarverk eller reportage, och då förstnämnda verks syfte bör anses ha varit att göra den ideella och samhälleliga åskådning, som framgick av Vuorimaas verk, till föremål för kritik och Salo med beaktande även av olikheten beträffande den litterära arten av Vuorimaas och Salos verk icke bör anses hava intagit citat i vidare omfattning än sagda syfte betingat, för den skull och då den omständigheten, att Salo i sitt verk icke omnämnt Vuorimaas verk, med hänsyn till citatens syfte och förenämnda huvudsakliga användningssätt, icke kunde anses vara stridande mot god sed och plagieringen ej heller eljest var kränkande för Vuorimaas upphovsrätt, förkastade HD åtalet och frikände Salo från det honom ådömda straffet samt frikallade honom från ifrågavarande skadeståndsskyldighet. II 44/1971.

Detta rättsfall kan måhända påräkna intresse, då den finska lagen om upphovsrätt till litterära och konstnärliga verk 8/7 1961 tillkommit som ett resultat av nordiskt samarbete på lagberedningens område. Motsvarande lagar har utfärdats i Sverige 30/12 1960, i Norge 12/5 1961 och i Danmark 31/5 1961.

\section{Förelåg brytande mot bestämmelse i lagen om rätt till fotografisk bild?}

15. Fotografen A anförde i RR, att sedan stadsstyrelsen i Lahtis stad utsett honom att utföra fotograferingen för ett fotografiskt verk, som skulle framställa sagda stad, och arbetsutskottet för den kommission stadsstyrelsen tillsatt för verkets publicering vid möte 2/12 1966 godkänt den plan han framlagt angående motiven för bilderna, hade kommissionen vid sam-. manträde 10/3 1967, till vilket A icke ens kallats, företagit vissa ändringar i planen samt vid sammanträde 12/4 1967, då A hörts, meddelat, att en del ändringar skulle företagas däri. A anförde ytterligare, att sedan han företagit vissa i den ändrade planen förutsatta omfotograferingar, varefter verket skulle vara färdigt, hade kommissionen ännu företagit vissa ändringar, vilka helt och hållet avveko från $\mathrm{A}$ : $\mathrm{s}$ helhetssyn på verket, varför $\mathrm{A}$ medelst skrivelse 7/6 1967 förbjudit verkets publicering och 19/6 
1967 upprepat sitt förbud. För den skull och då bildverket på åtgärd av kommissionen i oktober 1967 begynt spridas i Lahtis, yrkade A, att ordföranden för kommissionen, jurislicentiaten B skulle fällas till straff med stöd av $2 \S 2 \mathrm{mom}$. och $18 \S 1 \mathrm{mom}$. lagen om rätt till fotografisk bild 8/7 1961 för det denne trots A : s förbud icke hade avbrutit spridningen av bildverket, ehuru verket kränkte A:s anseende som fotograf, samt B:s skyldigkännande att utgiva åt $\mathrm{A}$ i vederlag för de av bildverket producerade 2.000 exemplaren efter en beräkningsgrund av $4 \mathrm{mk}$ för exemplar sammanlagt $8.000 \mathrm{mk}$. A yrkade ytterligare, att spridanden av bildverket skulle förbjudas. - RR ansåg utredning saknas därom, att A gjort sig skyldig till brott och ogillade de av A framställda yrkandena. A sökte ändring. - HovR: ej ändring. - HD: enär den av stadsstyrelsen i Lahtis stad för bildverkets publicering tillsatta kommissionen varit berättigad att företaga ändringar i den av A framlagda planen beträffande verkets bildmotiv och det icke utretts, att de av A framställda fotografierna skulle ändrats på ett sätt som kränkte A:s anseende som fotograf eller publicerats $i$ en form eller $i$ ett sammanhang som kränkte honom, fastställde HD med stöd av $2 \S 2$ mom. och $15 \S 1 \mathrm{mom}$. lagen om rätt till fotografisk bild det slut vartill HovR kommit. II 78/1970.

Den finska lagen om rätt till fotografisk bild 8/7 1961 har tillkommit såsom ett resultat av nordiskt samarbete på lagstiftningens område. Motsvarande lagar har stadfästs i Sverige 30/12 1960, i Norge 17/6 1960 och i Danmark 31/5 1961.

\section{Trafikförseelse.}

16. HR i Taivalkoski hade medelst 5/8 1970 avkunnat laga kraft vunnet utslag, jämte det finske medborgaren $A$, som var bosatt i staden Borås i konungariket Sverige, ådömdes straff bl. a. för framförande av motorfordon i alkoholpåverkat tillstånd och ovarsamhet i trafik, begångna i en gärning, med stöd av $10 \S$ 1 mom. lagen om vägtrafik 29/3 1957 förklarat det $A$ av länsstyrelsen i Älvsborgs län i Sverige beviljade körkortet förverkat samt föreskrivit, att A icke fick beviljas nytt körtillstånd före 5/8 1972. Enär sagda körkort med beaktande av bestämmelserna i den mellan Sverige och Finland angående ömsesidigt godkännande av körkort samt av registrering av motorfordon $\mathrm{m} . \mathrm{m}$. ingångna, medelst förordning 12/10 1956 i Finland i gällande kraft bragta överenskommelsen icke kunnat förklaras förverkat, hade den person, som vid målets avgörande fungerade såsom HR:s ordförande, medelst till HD ställd skrift anhållit, att HD skulle rätta ifrågavarande utslag så att det överensstämde med lag. - HD prövade lagligt på anförd grund med stöd av 31 kap. $8 \S 4$ punkten rättegångsbalken rätta ifrågavarande utslag så- 
lunda, att utlåtandet om att det i Sverige A beviljade körkortet förklarats förverkat undanröjdes, varjämte HD med stöd av 6 artikeln $1 \mathrm{mom}$. i förenämnda mellan Sverige och Finland ingångna överenskommelse förklarade, att sagda körkort icke berättigade A att före 5/8 1972 framföra motorfordon i Finland. Ytterligare förtydligade HD det i sagda utslag ingående utlåtandet angående beviljande av nytt körtillstånd sålunda, att detsamma avsåg förbud att i Finland bevilja A körtillstånd före sagda 5/8 1972. II 97/1971.

Av artikel 1 i den mellan Sverige och Finland angående ömsesidigt godkännande av körkort samt av registrering av motorfordon $\mathrm{m}$. m. ingångna överenskommelsen framgår, att körkort för förande av motorfordon (bil eller motorcykel) utfärdat i det ena landet (hemlandet) och där gällande, giver innehavaren rätt att under tillfälligt uppehåll av högst ett år i det andra landet (besökslandet) framföra motorfordon av det slag, vartill körkortet berättigar honom. I 6 artiklens 1 mom. stadgas bl. a., att därest villkoren för erhållande av körkort eller tillstånd uppenbarligen icke längre uppfyllas, eller körkorts- eller tillståndsinnehavaren gjort sig skyldig till sådan trafikförseelse, som jämlikt besökslandets lagstiftning medför återkallelse av körkort, äger vederbörande myndighet $\mathrm{i}$ detta land rätt att vägra godkännande, i förekommande fall för viss tid, av i det andra landet utfärdat körkort eller meddelat tillstånd.

\section{Yrkesmässig motorfordonstrafik.}

17. Allmän åklagare yrkade vid $R R$ traktorföraren $A: s$ fällande till straff för det denne i november och december $1967 \mathrm{i}$ Gamlakarleby stad mot ersättning med traktor forslat snö från några fastigheter utan vederbörligt tillstånd. - RR fann visserligen utrett, att $\mathrm{A}$ vid de $\mathrm{i}$ åtalet avsedda tillfällena på grund av de entreprenadavtal han ingått angående bortforsling av snö mot ersättning utfört ifrågavarande snötransporter utan tillstånd, men enär till dylika till renhållningsentreprenader anslutna transportuppdrag icke erfordrades tillstand, ogillade RR åtalet. Åklagaren sökte ändring. - HovR fann utrett, att A på i åtalet anfört sätt utfört snötransporter, vilka enligt vad av handlingarna i målet framgick icke anslutit sig till några renhållningsentreprenader och till vilkas utförande A sålunda bör anses hava behövt tillstånd, varför HovR med upphävande av RR:s utslag, med stöd av 65 § 1 mom. motorfordonsförordningen 4/10 1957 samt $5 \S 1$ mom. och 9 § lagen om vägtrafik 29/3 1957 bötfällde A för utövande av yrkesmässig trafik utan vederbörligt tillstånd. A anhöll om prejudikatdispens. - HD biföll ansökningen och fastställde HovR:s utslag i övrigt utom att det A ådömda bötesstraffet nedsattes. II $3 / 1970$. 
18. Allmän åklagare yrkade vid HR butiksföreståndaren A:s fällande till straff för det denne från år 1964 till 31/10 1968 i Pielisjärvi kommun, i egenskap av föreståndare för en i Nurmijärvi by av sagda kommun belägen, ett aktiebolag tillhörig butik, med sin ägande paketbil forslat eller låtit forsla varor från nämnda butik till bolagets kunder och mottagit av bolaget i ersättning härför $23-26$ p. per körkilometer, ehuru han icke innehaft erforderligt tillstănd för bedrivande av dylik yrkesmässig trafik. HR fann visserligen utrett, att A i sin förenämnda egenskap under den $\mathrm{i}$ åtalet angivna tiden med sin paketbil forslat eller låtit forsla varor till butikens å särskilda arbetsplatser belägna försäljningsställen samt till butikens kunder, ehuru han icke innehaft vederbörligt trafiktillstånd, och att han erhållit av bolaget $\mathrm{i}$ ersättning för sagda transporter $23-26$ p. per körkilometer, men enär ifrågavarande transporter hörde till de uppgifter som ålåg en butiksföreståndare vid utövande av köpmannayrket och då de för sagda transporter erlagda ersättningarna endast var avsedda att täcka resekostnaderna, ogillade HR, som ansåg, att $\mathrm{A}: \mathrm{s}$ ifrågavarande verksamhet icke kunde anses för utövande av sådan av tillstånd beroende yrkesmässig biltrafik, som avses i $65 \S 1$ mom. motorfordonsförordningen, åtalet. Åklagaren sökte ändring. - HovR fann utrett, att $A$ var saker till vad honom tillvitats, varför HovR, med upphävande av HR:s utslag, med stöd av $65 \S 1$ mom. motorfordonsförordningen samt $5 \S 1 \mathrm{mom}$. och 9 § lagen om vägtrafik bötfällde $\mathrm{A}$ för utövande av yrkesmässig trafik utan vederbörligt tillstånd. A anhöll om prejudikatdispens. - HD biföll ansökningen; och enär A genom att i sitt arbetsförhållande till bolaget med sin bil mot av bolaget utbetalda ersättningar utföra och låta utföra i åtalet avsedda körslor, som anslöt sig till hans arbetsgivares näringsverksamhet, icke kunde anses ha bedrivit yrkesmässig biltrafik, prövade HD rättvist, med upphävande av HovR:s utslag, ogilla åtalet. - Tvenne ledamöter fastställde HovR:s utslag. II 91/1970.

19. På åtalan av allmän åklagare förklarade HR utrett, att bilföraren $\mathrm{A}$ och bonden $\mathrm{B}$ hade från början av december 1968 till $17 / 21969$ i det av dem grundade ,Sorahuoltoyhtymä Viitanen ja Peltonen" benämnda öppna bolags namn med två av bolaget innehavde lastbilar mot ersättning utan vederbörligt tillstånd för bedrivande av beställningstrafik forslat grus, som de inköpt från ett på B:s ägande, i Lentilä by av Kuortane kommun belägna lägenhet befintligt grustag, till två firmor i Seinäjoki stad, ehuru transportverksamheten med beaktande av grustagets omfång och den korta tiden för dess användning borde, vid jämförelse med bolagets övriga verksamhet, anses för fristående förvärvsverksamhet, varför HR med stöd av $65 \S 1$ mom. och $85 \S$ motorfor- 
donsförordningen, $5 \S 1$ mom. och $9 \S$ lagen om vägtrafik samt 7 kap. $2 \S$ strafflagen bötfällde A och B för fortsatt utövande av yrkesmässig trafik utan vederbörligt tillstånd. A och B sökte ändring. - HovR fastställde HR: s utslag. A och B sökte ändring. - HD: enär A och $B$ då de med av nämnda öppna bolag innehavda lastbilar transporterade bolagets av B redan tidigare inköpta och sedermera till två byggnadsfirmor försålda grus till köparna med hänsyn därtill, att gruset försålts fritt levererat till av köparna anvisade platser och att grusforslingen sålunda skett för säljarens räkning, icke hade mot ersättning betjänat allmänheten eller en viss uppdragsgivare, prövade HD rättvist, med upphävande av de lägre instansernas utslag, ogilla åtalet. — Dissens beträffande motiveringen. - II 99/1970.

Den numera upphävda $65 \S 1 \mathrm{mom}$. motorfordonsförordningen 4/10 1957 lydde vid ifrågavarande trafikbrotts begående och målens avgörande sålunda: „Den, som mot ersättning ärnar betjäna allmänheten eller viss uppdragsgivare genom att med bil befordra personer eller gods eller båda, skall utverka tillstånd att bedriva sådan yrkesmässig trafik."

I rättsfallet 17 hade A med sin med lastningsskopa försedda traktor, vid vilken var fäst en släpvagn, transporterat c. 40 lass snö frản tre fastigheters gångbanor till stadens snöavstjälpningsplats. Forslingen utförde A på grund av avtal, som han ingått med fastighetsägarena. Rengöringen av gångbanorna ålåg fastigheternas gårdskarlar. HD torde i sitt utslag utgått från att begreppet yrkesmässig trafik förutsätter, att den mot ersättning skeende verksamheten åtminstone huvudsakligen utgör befordring av personer eller gods eller av båda. Är befordringen endast accessorisk i förhållande till eventuell övrig verksamhet föreligger icke yrkesmässig trafik och tillstånd erfordras icke. Följande exempel har framförts i facklitteraturen: En person, som förbundit sig att vintertid reparera ett hus, skottar för att möjliggöra reparationen snön från husets tak direkt i sin ägande lastbil och transporterar snön till avstjälpningsplatsen. Sagda transport ansluter sig som en oväsentlig del till avtalet angående reparationen av taket och tillstând erfordras icke. Utgör verksamheten åter huvudsakligen transport av snö mot ersättning, vare sig denna bestämmes enligt antalet transporterade lass eller enligt beting, föreligger yrkesmässig trafik och tillstånd erfordras (Lehkonen: Ammattimaisen autoliikenteen käsitteestä y.m., Ammattiautoilija $1961 \mathrm{~N}$ : o $9 \mathrm{~s}$. 10-11, „Om den yrkesmässiga biltrafikens begrepp m. m., tidskriften Yrkesbilisten 1961.“). I rättsfallet 17 utgjorde det mot ersättning utförda arbetet enbart transport av snö, m.a.o. befordring av gods.

I rättsfallet 18 torde $\mathrm{HD}: \mathrm{s}$ majoritet ansett, att $\mathrm{A}$ i egenskap av butiksföreståndare stod i arbetsförhållande till bolaget och 
att transporten av varorna till ifrågavarande försäljningsställen och bolagets kunder endast var en oväsentlig del av den verksamhet, som grundade sig på arbetsförhållandet även i det fall, att A icke själv körde bilen. Minoriteten torde åter utgått från att A enligt det avtal han slutit med bolaget måhända ålåg att ombesörja transporterna till försäljningsställena och bolagets kunder, men att själva utförandet av transporterna med A:s egen bil mot ersättning icke ingick som en del i sagda avtal. A skulle i detta fall ha bedrivit självständig näringsverksamhet.

I rättsfallet 19 konstaterade HD, att gruset redan före transporten inköpts av bolaget och av detta försålts fritt levererat till av köparna anvisade platser; då grusforslingen sålunda skett för bolagets räkning, hade $\mathrm{A}$ och $\mathrm{B}$ icke mot ersättning betjänat allmänheten eller en viss uppdragsgivare.

Nämnas må, att 12 kap. motorfordonsförordningen, vari ofta åberopade 65 § ingick, ersatts med förordningen om yrkesmässig motorfordonstrafik 16/10 1970, vilken trädde i kraft 1/1 1971. Av $2 \S 1$ mom. sistnämnda förordning framgår, att begreppet yrkesmässig trafik icke undergått förändring; i sagda paragrafs andra moment har intagits ett stadgande, som avser att hindra kringgående av bestämmelserna om dylik trafik.

\section{Förbruten egendom.}

20. A hade jämte en annan person natten mot 7/4 $1970 \mathrm{i}$ Viiala by av Sippola kommun med inbrott stulit från en butik bl. a. cigaretter till ett värde av $5.117 \mathrm{mk} 25 \mathrm{p}$. Av cigaretterna hade B, som visste att dessa åtkommits genom stöld, samma dag för 1.000 mk tillhandlat sig ett parti, vars värde uppgick till $2.497 \mathrm{mk} 91 \mathrm{p}$. HR fällde A och B till straff, A för grov stöld och B för döljande av tjuvgods samt dömde med stöd av 2 kap. $16 \S 1$ och $3 \mathrm{mom}$. strafflagen den ekonomiska fördel A erhållit genom stölden eller $1.000 \mathrm{mk}$ förbruten till staten. A sökte ändring. — HovR: ej skäl. A sökte ändring. - HD: ej annan ändring än att, enär A, oaktat $B$ vetat att de cigaretter han köpt av A och vilka sedermera återfåtts åtkommits genom stöld, var pliktig att återställa till B det pris han av denne erhållit för cigaretterna och A av ifrågavarande stöldsbrott sålunda icke erhållit sådan ekonomisk fördel, som avses i 2 kap. $16 \S$ strafflagen, frikallades $\mathrm{A}$ från att utbetala åt staten ifrågavarande $1.000 \mathrm{mk}$. - Utslaget gavs efter omröstning; 3 ledamöter omfattade utslaget medan en ledamot förenade sig om det slut, vartill HD i sitt utslag kommit och en ledamot fastställde HovR:s utslag. II 96/1970.

B visste alltså att det parti cigaretter kan köpte av A var gods, som denne åtkommit genom stöld. Partiet fråntogs B och återställdes till rätta ägaren. HD har nu fastslagit, att köparen B äger av A kräva det pris han till denne erlagt för cigarettpartiet. 
men framställde icke något anspråk; konfiskationsyrkandena ogillades.

21. A hade $22 / 11969$ vid avresa med sin ägande personbil från Helsingfors till utlandet $\mathrm{i}$ strid med gällande reglementeringsbestämmelser utfört $3.000 \mathrm{mk}$ samt 26/1 1969 i Åbo vid återkomsten till Finland, i avsikt att bereda sig nytta, infört i landet undandragande statsverket detta tillkommande tullavgift en ny motor, som han i Förbundsrepubliken Tyskland låtit insätta i bilen, varom han icke underrättat tullmyndigheterna. För den skull och då bilen huvudsakligen använts till färd, som avsåg forsling av den till landet införda motorn, dömde de lägre instanserna med stöd av statsrådets beslut om reglementering av valutan 17/12 1959, 9 § lagen om bestraffning av brott mot vissa fullmaktslagar 28/6 1958 samt 38 kap. 11, 12 och 15 §§ samt 7 kap. $2 \S$ strafflagen A till straff för fortsatt brott, som innebar lurendrejeri och tullförsnillning, samt förklarade såväl sagda 3.000 mk som den i beslag tagna personbilen förbrutna till statsverket. A sökte ändring. — HD: ej annan ändring än att, enär A utfört ur landet ifrågavarande penningsumma i avsikt att å sin bil låta utföra en reparation, som innebar bl. a. byte av motor, och A, vilken använt penningarna för sagda ändamål, icke kunde förutom bilen förklaras förlustig även det belopp han använt för utförande av reparationen, frikallades A från att utbetala åt statsverket ifrågavarande $3.000 \mathrm{mk}$. Bilen förklarades förbruten, alldenstund densamma använts till färd, som huvudsakligen avsåg lurendrejeri och tullförsnillning. II 45/1970.

Ett närastående rättsfall är II $1 / 1965$, för vilket redogjorts i översikten för perioden 1961-1969 under rättsfall 37. Enligt $9 \S$ lagen om bestraffning av brott mot vissa fullmaktslagar skall A för sagda olovliga valutautförsel ådömas straff och övriga påföljder enligt stadgandena angående lurendrejeri i 38 kap. 12 och $15 \S \S$ strafflagen. Jämlikt sistnämnda lagrum skulle såväl penningbeloppet som bilen, som använts till utfärden från Finland, vilken färd huvudsakligen avsåg lurendrejeri, dömas förbrutna. Då A sedermera på omförmält sätt införde ifrågavarande motor till landet undandragande statsverket detta tillkommande tullavgift gjorde A sig saker till tullförsnillning, varför honom med stöd av sagda kapitels $11 \S$ bör ådömas straff och jämlikt nämnda $15 \S$ bör bilen, vilken använts till färd, avseende huvudsakligen tullförsnillning, även av denna anledning förklaras förbruten. HD har nu på anförd grund ansett, att ifrågavarande penningbelopp icke bör jämte bilen dömas förbruten. - Beaktande förtjänar även rättsfallet II 57/1969: A hade försökt att med undandragande av statsverket tillkommande tullavgift till landet införa en ny motor, som han på färden inmonterat i en 
annan persons bil; då bilen använts till färd, som huvudsakligen avsåg tullförsnillning, dömdes $\mathrm{A}$ med stöd av nyssnämnda lagrum att till staten förverka värdet av bilen. I detta fall dömdes värdet av bilen förbruten, enär bilens ägare icke ens påståtts hava varit delaktig i brottet och $\mathrm{A}$ icke handlat till förmån för denne.

\section{Nådeärende.}

22. A, vilken 4/10 1968 blivit villkorligt frigiven från tvångsinrättning med prövotid, som utgick 4/10 1973, anhöll hos Republikens president, att han av nåd måtte anses hava blivit ovillkorligen frigiven från sagda inrättning eller att den till den villkorliga friheten hörande övervakningen åtminstone skulle inställas. I avgivet utlåtande framhöll HD att skäl icke förelåge att bifalla ansökningen till dess förra del och att, enär inställande av den till den villkorliga friheten anslutna övervakningen, med beaktande även av stadgandena i 2 kap. 14 a $\S 3$ mom. förordningen om verkställighet av straff $19 / 121889$ och 13 \& mom. förordningen angående tvångsinrättning 21/6 1954, icke kunde medgivas $\mathrm{i}$ benådningsväg, ansökningen i sistnämnda avseende skulle lämnas utan avseende. Republikens president lämnade 30/10 1970 ansökningen såvitt den berörde inställande av ifrågavarande övervakning utan avseende. II 75/1970.

Såsom tidigare framhållits (Finska domar i brottmål 19611969 årgång 1970 s. 62) har stadgandet i 29 § 1 mom. Regeringsformen angående den Republikens president tillkommande benådningsrätten tolkats extensivt. Benådningsrätten har i vissa fall utsträckts till straffverkställigheten. Även person, som enligt lagen om internering av farliga återfallsförbrytare 9/7 1933 förordnats till internering i tvångsinrättning, har ansetts i benådningsväg kunna villkorligt frigivas. Dylik internering kan icke betraktas såsom straffverkställighet i egentlig mening; den är väl snarare att anse som ett förfarande, varigenom samhället söker skydda sig mot särskilt farliga brottslingar. Enligt sagda lag skall domstol, då den dömer i nämnda lag avsedd person till däri avsett straff, samtidigt, när den dömde bör anses vådlig för den allmänna eller enskilda säkerheten, besluta, att han må förordnas till internering i tvångsinrättning; finnes sedan vid straffverkställigheten eller anses av annan orsak, att straffet icke förbättrar den dömde, skall en särskild domstol, fängelsedomstolen, innan straffet till fullo har utståts, förordna, att han bör interneras i tvångsinrättning. I dylik inrättning internerad, som varit intagen i straff- och tvångsinrättning sammanlagt ett år utöver tiden för det ådömda frihetsstraffet, dock sammanlagt minst två år, må enligt förordnande av fängelsedomstolen bliva villkorligt frigiven med en prövotid av fem år, såvida han icke längre anses 
vådlig för den allmänna eller enskilda säkerheten. Jämlikt $13 \S$ 2 mom. förordningen angående tvångsinrättning skall på intern, som från tvångsinrättning blivit försatt $i$ villkorlig frihet $i$ motsvarande mån tillämpas vad om från straffanstalt i villkorlig frihet försatt fånge är stadgat. Från straffanstalt villkorligt frigiven skall under prövotiden stå under i lag stadgad övervakning, om icke på synnerliga skäl beslutes, att övervakning icke erfordras. Avsikten med övervakningen är att hindra den i villkorlig frihet försatta att begå nytt brott och att stöda honom i hans strävanden till otadligt leverne. Jämlikt 14 a $§ 3$ mom. förordningen om verkställighet av straff kan justitieministeriet under $i$ sagda lagrum angivna förutsättningar förordna om inställande av övervakningen. Dylikt förordnande och sålunda även liknande förordnande, som gäller intern, som från tvångsinrättning blivit försatt $i$ villkorlig frihet, är till sin natur väl närmast en åtgärd av förvaltningsrättslig karaktär. Därför har i förevarande nådeärende även ansetts, att inställande av övervakning av person, som från tvångsinrättning försatts i villkorlig frihet, icke kan utgöra föremål för statschefens benådningsrätt.

Viking Modeen. 